\title{
Article \\ Genome-Wide Association Analysis of Salt-Tolerant Traits in Terrestrial Cotton at Seedling Stage
}

\author{
Juyun Zheng ${ }^{1,+}$, Zeliang Zhang ${ }^{1,2,+}$, Zhaolong Gong ${ }^{1,+}$, Yajun Liang ${ }^{1}$, Zhiwei Sang ${ }^{1,2}$, Yanchao Xu ${ }^{3}$, \\ Xueyuan $\mathrm{Li}^{1, *}$ and Junduo Wang ${ }^{1, *}$ \\ 1 Economic Crops Research Institute, Xinjiang Academy of Agricultural Science (XAAS), \\ Urumqi 830001, China; zjypp8866@126.com (J.Z.); zzldeyouxiang@126.com (Z.Z.); \\ zhangzeliang8866@163.com (Z.G.); 13999966149@163.com (Y.L.); s2564976727@163.com (Z.S.) \\ 2 Engineering Research Centre of Cotton, Ministry of Education, College of Agriculture, \\ Xinjiang Agricultural University, 311 Nongda East Road, Urumqi 830052, China \\ 3 State Key Laboratory of Cotton Biology (China), Institute of Cotton Research, Chinese Academy of \\ Agricultural Science (ICR-CAAS), Anyang 455000, China; b27274092@163.com \\ * Correspondence: xjmh2338@163.com (X.L.); 13579975299@163.com (J.W.) \\ + These authors contributed equally to this work.
}

check for

updates

Citation: Zheng, J.; Zhang, Z.; Gong, Z.; Liang, Y.; Sang, Z.; Xu, Y.; Li, X.; Wang, J. Genome-Wide Association Analysis of Salt-Tolerant Traits in Terrestrial Cotton at Seedling Stage. Plants 2022, 11, 97. https:// doi.org/10.3390/plants11010097

Academic Editor: Yong-Gu Cho

Received: 11 October 2021

Accepted: 11 December 2021

Published: 29 December 2021

Publisher's Note: MDPI stays neutral with regard to jurisdictional claims in published maps and institutional affiliations.

Copyright: (c) 2021 by the authors. Licensee MDPI, Basel, Switzerland. This article is an open access article distributed under the terms and conditions of the Creative Commons Attribution (CC BY) license (https:/ / creativecommons.org/licenses/by/ $4.0 /)$.

\begin{abstract}
Soil salinization is the main abiotic stress factor affecting agricultural production worldwide, and salt stress has a significant impact on plant growth and development. Cotton is one of the most salt-tolerant crops. Therefore, the selection and utilization of salt-tolerant germplasm resources and the excavation of salt resistance genes play important roles in improving cotton production in saline-alkali soils. In this study, we analysed the population structure and genetic diversity of a total 149 cotton plant materials including 137 elite Gossypium hirsutum cultivar accessions collected from China and 12 elite Gossypium hirsutum cultivar accessions collected from around the world. Illumina Cotton SNP $70 \mathrm{~K}$ was used to obtain genome-wide single-nucleotide polymorphism (SNP) data for 149 elite Gossypium hirsutum cultivar accessions, and 18,430 highly consistent SNP loci were obtained by filtering. It was assessed by using PCA principal component analysis so that the 149 elite Gossypium hirsutum cultivar accessions could be divided into two subgroups, including subgroup 1 with 78 materials and subgroup 2 with 71 materials. Using the obtained SNP and other marker genotype test results, under salt stress, the salt tolerance traits $3 \mathrm{~d}$ Germination potential, $3 \mathrm{~d}$ Radicle length drop rate, $7 \mathrm{~d}$ Germination rate, $7 \mathrm{~d}$ Radicle length drop rate, $7 \mathrm{~d}$ Germination weight, 3d Radicle length, $7 d$ Radicle length, Relative Germination potential, Relative Germination rate, 7d Radicle weight drop rate, Salt tolerance index $3 d$ Germination potential index, 3d Radicle length index, $7 d$ Radicle length index, $7 \mathrm{~d}$ Radicle weight index and 7d Germination rate index were evaluated by GWAS (genome-wide association analysis). A total of 27 SNP markers closely related to the salt tolerance traits and 15 SNP markers closely related to the salt tolerance index were detected. At the SNP locus associated with phenotyping, Gh_D01G0943,Gh_D01G0945,Gh_A01G0906,Gh_A01G0908, Gh_D08G1308 and Gh_D08G1309 related to plant salt tolerance were detected, and they were found to be involved in intracellular transport, sucrose synthesis, osmotic pressure balance, transmembrane transport, N-glycosylation, auxin response and cell amplification. This study provides a theoretical basis for the selection and breeding of salt-tolerant upland cotton varieties.
\end{abstract}

Keywords: upland cotton; salt stress; SNP; GWAS; salt tolerance gene

\section{Introduction}

Soil salinization is one of the main abiotic stress factors affecting agricultural production worldwide, and salt stress has significant impacts on plant growth and development. Under salt treatment, seed germination, root length, plant height and fruit development are significantly inhibited [1]. Salt stress can decrease cotton yield by up to 50-67\% [2]. The availability of salt-tolerant varieties would expand the area of cotton production by 
promoting the synchronous growth of food crops and cotton. Therefore, screening and utilizing excellent salt-alkali-tolerant germplasm resources and salt-tolerant genes play important roles in the transformation and utilization of saline-alkali land and improving the level of agricultural production in saline-alkali land. The damage to cotton caused by salt stress is mainly related to the effects of salt ions on the structure and function of young organs or cell membranes during the developmental transition period, which inhibits the growth of cotton seedlings, affects the growth process, reduces the number of total fruit nodes and reduces yield and quality [3-5].

Salt tolerance is a complex quantitative trait, which is controlled by multiple genes and involves a variety of physiological and biochemical metabolic pathways in cotton [6]. Quantitative trait locus (QTL) mapping of salt-related traits has become an effective approach. Compared to traditional QTL mapping, GWAS uses genome-wide SNPs as molecular markers to dissect the genetic basis of complex traits [7]. High-throughput genotyping platforms play an important role in plant genome research. GWAS was conducted for salt tolerance at the seedling stage using 419 upland cotton accessions and 17,264 SNPs [8]. Similarly, Cai et al. (2017) constructed a high-density 80K SNP cotton chip that contained 77,774 SNP sites, among which 352 cotton materials were analysed, and $76.51 \%$ of the sites were polymorphic [9]. The chip was utilized to perform a GWAS analysis of 288 upland cotton materials and found that eight SNPs were significantly associated with three salt tolerance traits. A GWAS was performed to identify marker-trait associations and 713 upland cotton accessions were phenotyped under salt stress and genotyped by the Illumina Infinium CottonSNP63K array [10]. Huang et al. (2017) used the US 63K chip to perform GWAS analysis on 503 upland cotton resources (63K) and identified 324 SNPs and 160 QTLs related to 16 agronomic traits, of which 38 related areas controlled 2 or more traits [11]. Paterson et al. (2012) used a population of upland cotton (440 materials) and a population of sea island cotton (219 materials) and the genotyping-by-sequencing (GBS) method to develop 10,129 SNP markers, and they obtained monomer domains in the whole gene range through analysis [12]. Abdelraheem et al. (2020) studied tolerant and sensitive alleles recombined for tolerance to the abiotic stress during the intermating process for population development: 23 QTL were detected for salt tolerance including 12 and 11 QTL for plant height and dry shoot weight, respectively [13]. Many QTLs were mapped on A05, A08, A09, A11, D01, D08, D09, D10 and D12 for salt tolerance in tetraploid cotton. $\mathrm{Xu}$ et al. (2021) found a locus on chromosome A13 and D08 associated with relative plant height (RPH), and loci on A07 for relative shoot fresh matter weight (RSFW); A08 and A13 for relative shoot dry matter weight (RSDW) were expressed in both environments and the increase in GH_A13G0171-silenced plants' salt tolerance under salt stress indicated its negative function in regulating the salt stress response [6].

In recent years, with increasing rainwater and serious secondary salinization, it has been crucial to study the salt tolerance traits of cotton at seedling stage. Cultivation of salttolerant crop varieties is an important way to achieve sustainable agricultural development in the future. Similar to other crops, excessive salts in the soil severely affect germination and seedling, particularly at sensitive stages in the life of a plant [14-16]. However, the salt tolerance of plants is a very complicated process. In this study, 149 elite Gossypium hirsutum cultivar accessions (lines) were used as materials, and 70K SNP chips were used to screen SNP loci and perform genome-wide association analysis on the traits related to salt tolerance at the seedling stage to find significant association sites related to salt tolerance. This study provides a reference and basis for further theoretical studies, such as the isolation of related genes and molecular marker-assisted selection of cotton salt tolerance. 


\section{Results}

\subsection{Genetic Diversity Analysis and Population Structure}

\subsubsection{Group Structure}

It is important for GWAS analysis to control the effect of population structure because population stratification could eliminate spurious associations between genotypes and phenotypes [17,18]. In total, 18,430 highly consistent SNP sites were obtained. PCA found that 149 individuals of upland cotton could be divided into two subgroups, including subgroup 1 (marked in red) consisting of 78 materials, and subgroup 2 consisting of 71 individuals, with PC1 9.25\% and PC2 5.2\%, respectively. Based on the analysis of the phylogenetic tree constructed from the SNP data, the 149 cotton plant accessions could be divided into two subgroups. The results are quite consistent with the grouping structure of PCA (Figure 1B). The hybrid model was used in ADMIXTURE V250 software. First, the number of subgroups $(K)$ was set to $1-20$, and each $K$ value was set to three repetitions. Assuming that each site was independent, the Markov chain Monte Carlo (MCMC), at the beginning of the non-count iteration (length of burn-in period), was set to 10,000 times, and then the MCMC, after no-count iterations, was set to 1,000,000 times. The optimal K value was selected according to the principle of maximum likelihood value to determine the number of subgroups and the group structure. The cross-validation error (CV error) was calculated under different $K$ values (2-20). In this experiment, using the $Q$ value calculation and Structure software, when $\mathrm{K}$ was equal to 18 , the $\mathrm{CV}$ error value was the smallest (Figure 1C). Taking the corresponding Q-matrix at $\mathrm{k}=18$ as the covariate could reasonably eliminate spurious association effects and improve the GWAS accuracy. The cotton population showed a certain distribution gap, but most varieties were clustered together, which corresponded to the actuality that the early introduction of Chinese land cotton varieties were mainly from the United States and the Soviet Union, and breeding used the introduced materials as the parents. The results showed that the division of the subgroups was significantly correlated with the material source, indicating that the genetic background of the resources was relatively homogeneous. For subgroups, the results of population structure analysis were in line with the evolutionary trends of the genetic background during breeding.

\subsubsection{Material Heterozygosity}

The individual heterozygosity analysis found that $95 \%$ of the cotton accessions were less than $30 \%$ heterozygous, and $80 \%$ of the individual materials were less than $5 \%$ heterozygous (Figure 2). Possible misalignment caused by homologous exchange (HEs) was prevalent in heterologous tetraploid crops, but, in cotton, HEs remained at a low level according to previous studies and had little effect on the results [19].

\subsubsection{Kinship Distribution}

Figure 3 shows that the 149 cotton varieties can be divided into two subgroups. Among the 149 varieties, the genetic relationships between most varieties were weak (the yellow parts in the figure), and the genetic relationships between a few materials were very close (the dark red parts in the picture). 

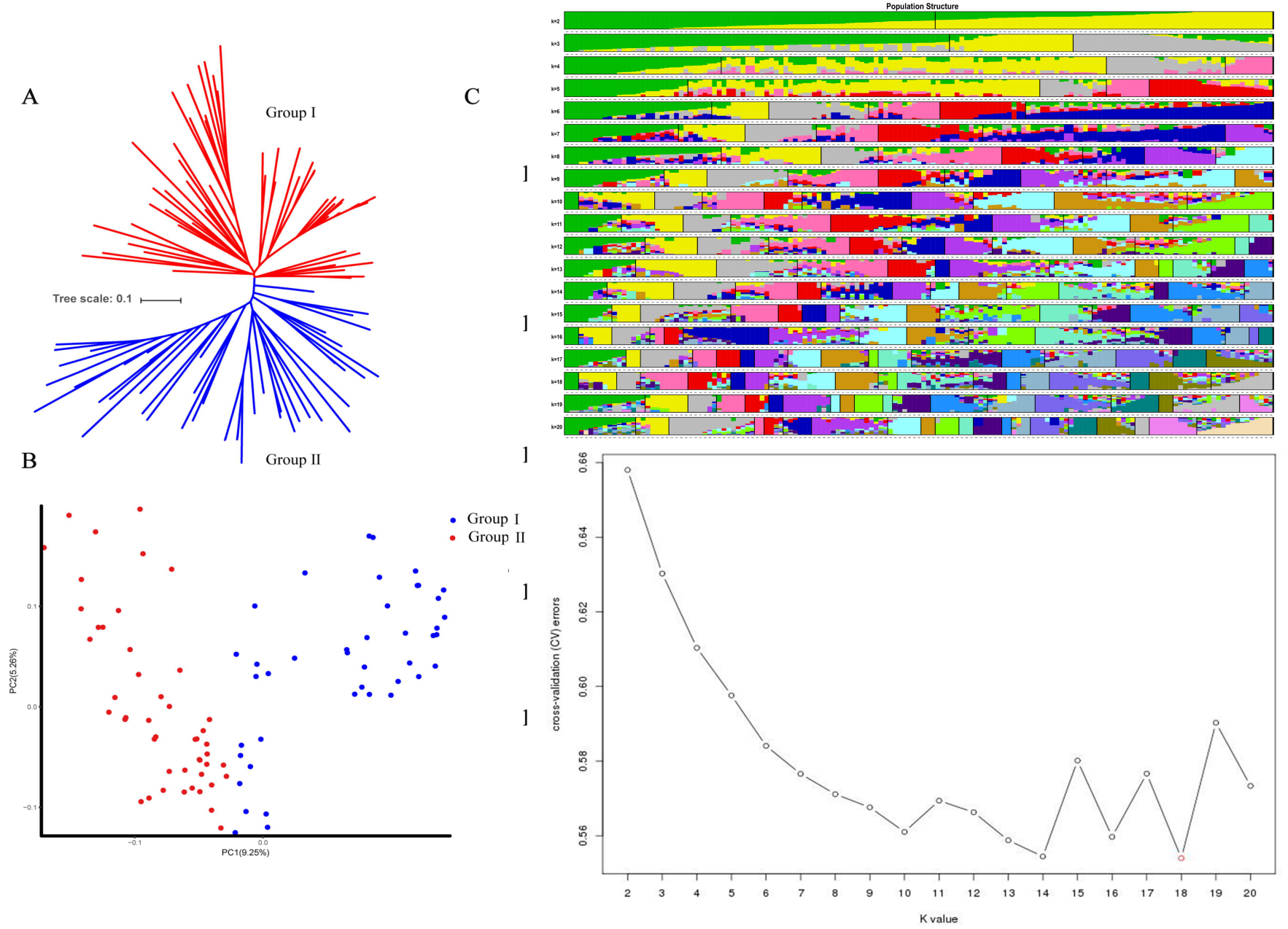

Figure 1. Analysis of groups based on structure. (A) NJ tree; (B) A scatter plot of principal component analysis (PCA); (C) Estimated population structure.
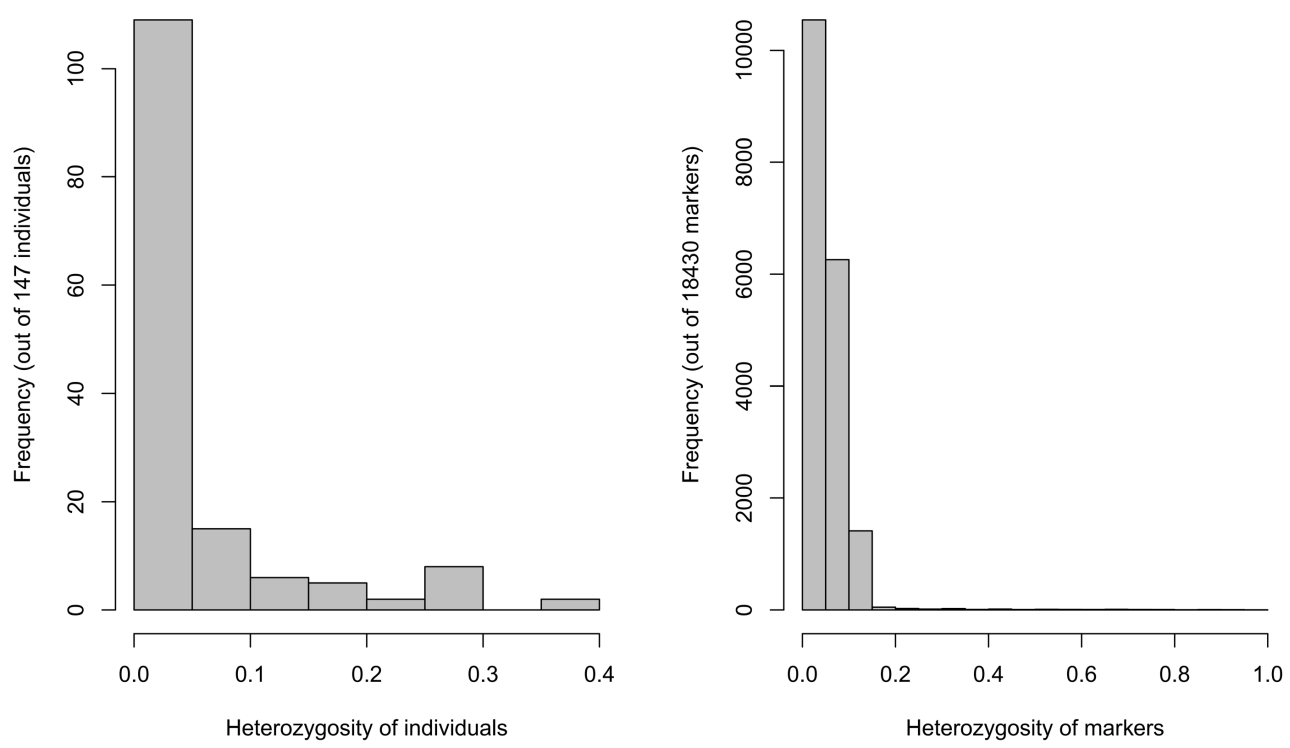

Figure 2. Frequency distribution of plant material heterozygosity and distribution of labelled heterozygosity. 

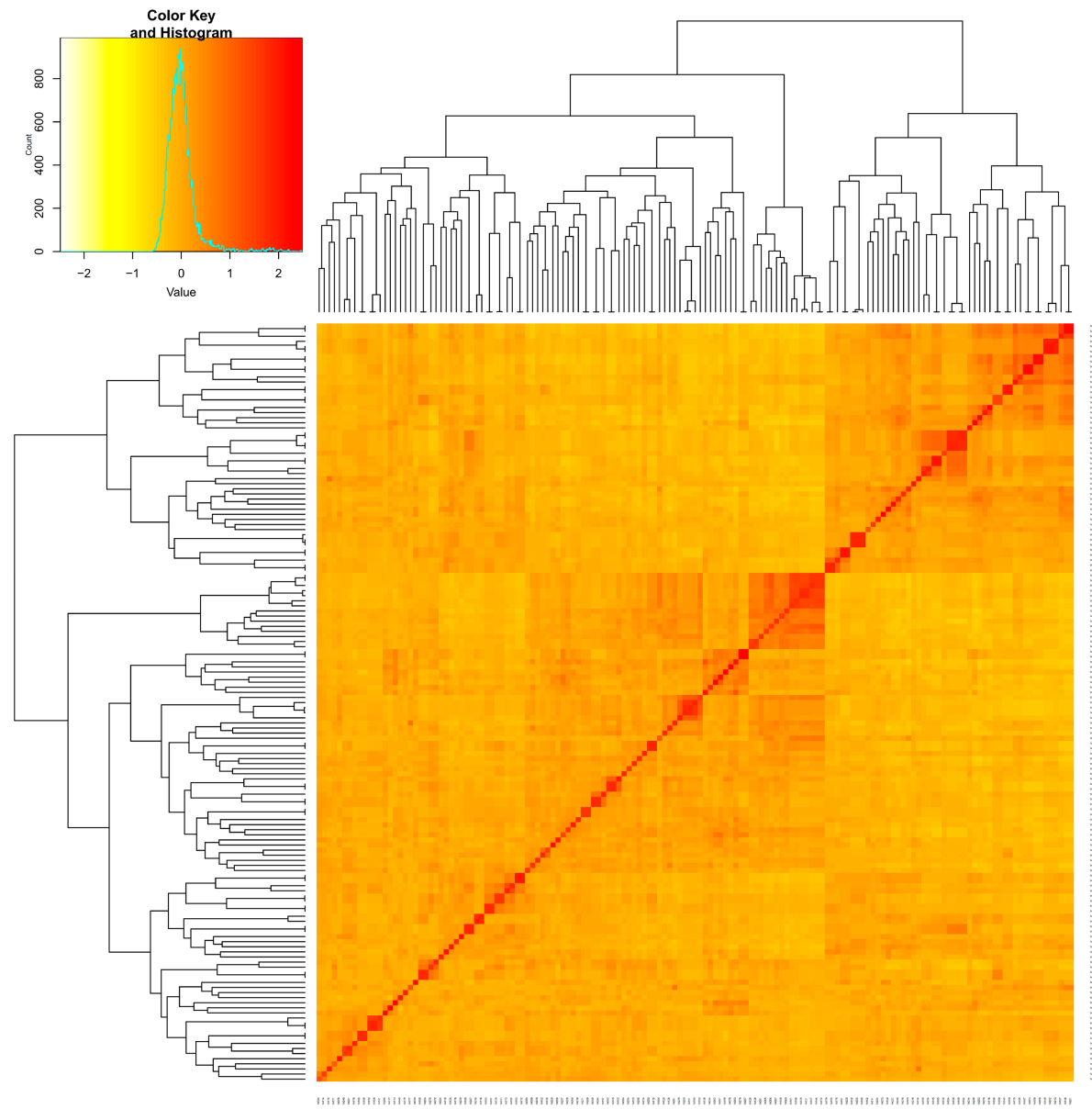

Figure 3. Heat map and cluster analysis based on the genetic relationship of 149 upland cotton varieties.

\subsubsection{Analysis of Linkage Disequilibrium}

The LD distance decreases as the physical position of the SNP on the chromosome increases. The analysis found that the LD distance of 149 samples was $432 \mathrm{~kb}(\mathrm{R}$ square $=0.5)$ (Figure 4). Slightly higher than the previous study [20] where Chinese upland cotton material was $296 \mathrm{~kb}$. This result further shows that the genetic diversity of the selected material is reduced. The genetic differentiation history of cotton collected in China is relatively low. This is related to the tended homogenization of Chinese cotton breeding.

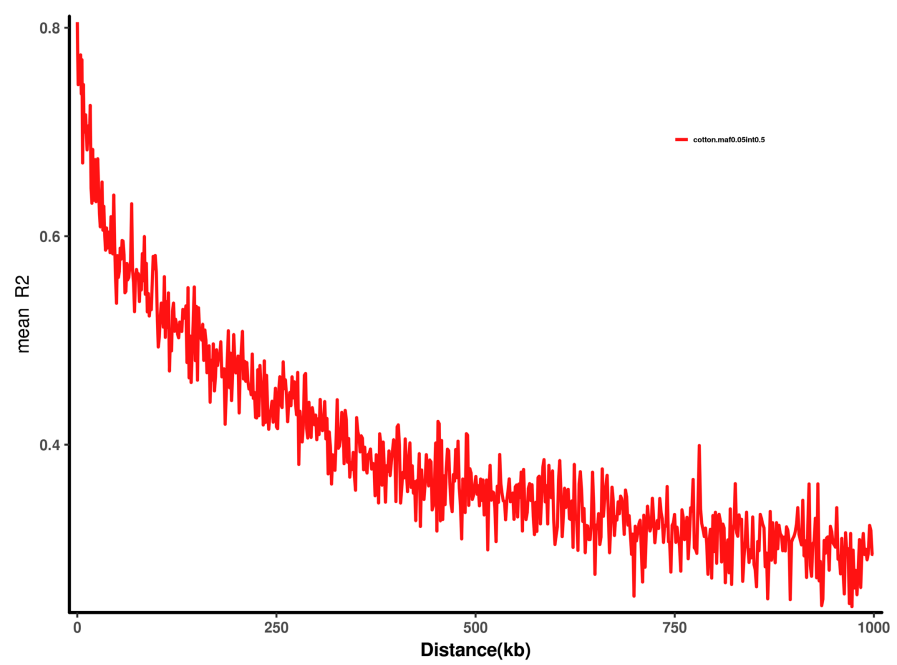

Figure 4. LD attenuation analysis of 149 cotton accessions. 
A
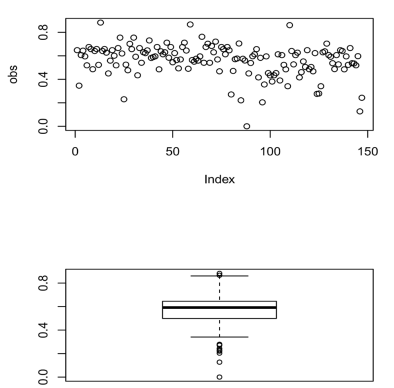

$\mathrm{C}$
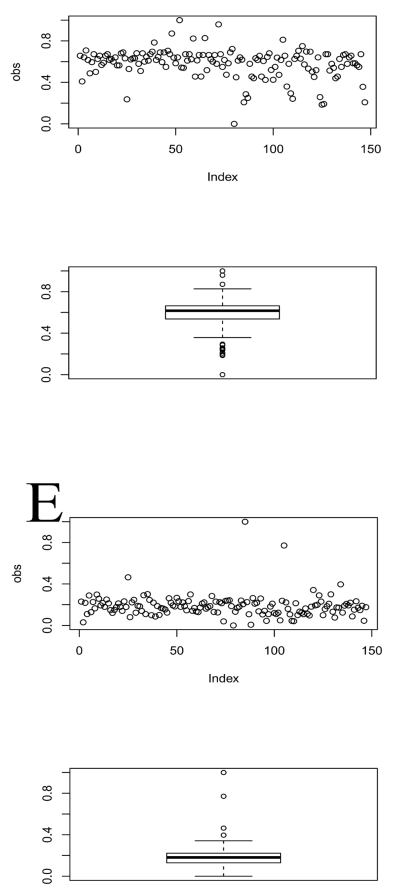

\subsection{Phenotypic Statistical Analysis}

In the best linear unbiased prediction (BLUP) for salt tolerance index traits, a total of five salt tolerance index phenotypic traits, $3 \mathrm{~d}$ Germination potential index, $3 \mathrm{~d}$ Radicle length index, $7 \mathrm{~d}$ Radicle length index, $7 \mathrm{~d}$ Radicle weight index, $7 \mathrm{~d}$ Germination rate index, were identified. Figure 5 shows that the phenotypic distributions of the five traits were all normally distributed ( $p$-value $>0.05$ ), indicating that these traits are all typical quantitative traits and are controlled by minor-effect polygenes. Using $\mathrm{R}$ language to calculate the Pearson correlation coefficients between traits, it was found that the correlations between different traits were low (Table 1).

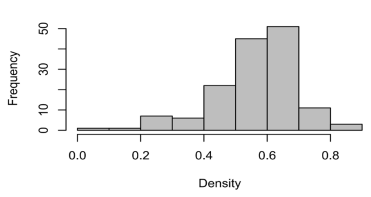

\section{B}
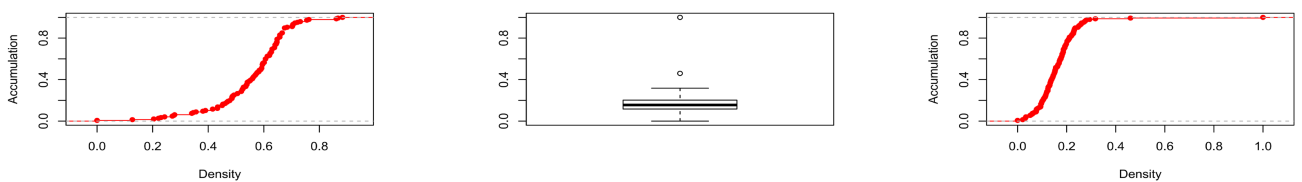

$\mathrm{D}$
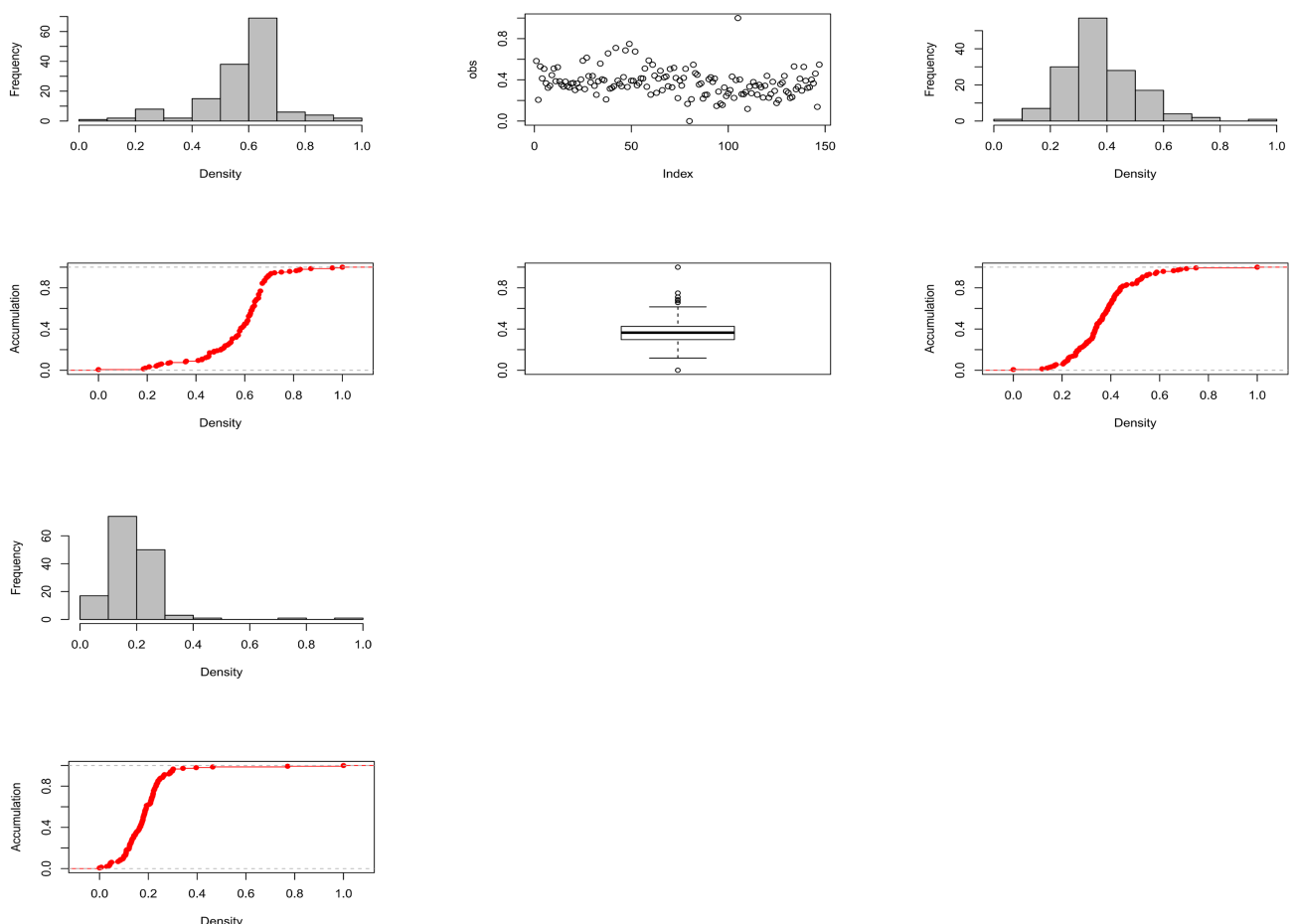

Figure 5. Distribution of traits in the three environments. (A) 3d Germination potential index BLUP analyse; (B) 3d Radicle length index BLUP analyse; (C) 7d Radicle length index BLUP analyse; (D) 7d Radicle weight index BLUP analyse; (E) 7d Germination rate index BLUP analyse. 
Table 1. Correlation analysis of salt tolerance index traits.

\begin{tabular}{cccccc}
\hline & $\begin{array}{c}\text { 3d Germination } \\
\text { Potential Index }\end{array}$ & $\begin{array}{c}\text { 7d Germination } \\
\text { Rate Index }\end{array}$ & $\begin{array}{c}\text { 7d Radicle } \\
\text { Weight Index }\end{array}$ & $\begin{array}{c}\text { 3d Radicle } \\
\text { Length Index }\end{array}$ & $\begin{array}{c}\text { 7d Radicle } \\
\text { Length Index }\end{array}$ \\
\hline 3d Germination potential index & 1 & 0.565096 & 0.330095 & 0.006608 & 0.178595 \\
7d Germination rate index & 0.565096 & 1 & 0.484635 & 0.000286 & -0.03288 \\
7d Radicle weight index & 0.330095 & 0.484635 & 1 & 0.475708 & 0.192883 \\
3d Radicle length index & 0.006608 & 0.000286 & 0.475708 & 1 & 0.230305 \\
7d Radicle length index & 0.178595 & -0.03288 & 0.192883 & 0.230305 & 1 \\
\hline
\end{tabular}

\subsection{Association Analysis of Salt Tolerance Traits}

Based on the identification results of the morphological, physiological, biochemical and yield traits of the specific germplasms of upland cotton under saline-alkali stress, an association analysis of the salt tolerance traits was carried out, and the favorable alleles related to the salt tolerance of the specific germplasm of upland cotton were located. A total of 27 SNP sites related to salt tolerance traits were detected (Table 2): 3 SNP sites related to 7d Radicle length; 10 SNP sites related to 7d Radicle length drop rate; 3 SNP sites related to 7d Germination rate; 3 SNP sites related to 7d Germination weight; 8 SNP sites related to Relative germination rate. The marker loci were scattered on six cotton chromosomes, A01, D01, D05, D08, D11 and D13, without clustering, and six QTLs related to salt tolerance traits were located on different chromosomes (Table 2). The research and development of SNP markers and QTL sites closely related to salt tolerance traits can be applied to the molecular marker-assisted selection of cotton salt tolerance.

Table 2. SNP sites related to salt tolerance traits in cotton accessions.

\begin{tabular}{|c|c|c|c|c|c|}
\hline Traits & Chromosomes & Position & $p$-Value & $-\log 10(p)$ & Alleles \\
\hline \multirow{3}{*}{ 7d Radicle length } & D08 & $64,320,143$ & 0.000019 & 4.731944 & $\mathrm{~T} / \mathrm{G}$ \\
\hline & D13 & $35,877,478$ & 0.000046 & 4.334531 & $\mathrm{C} / \mathrm{T}$ \\
\hline & scaffold33030 & 93 & 0.000099 & 4.004747 & $\mathrm{~A} / \mathrm{C}$ \\
\hline \multirow{10}{*}{$7 \mathrm{~d}$ Radicle length drop rate } & D01 & $16,458,717$ & 0.000000 & 6.588126 & $\mathrm{~T} / \mathrm{C}$ \\
\hline & A01 & $22,140,802$ & 0.000001 & 6.1328 & $\mathrm{~T} / \mathrm{C}$ \\
\hline & A01 & $22,174,537$ & 0.000001 & 6.1328 & $\mathrm{~T} / \mathrm{C}$ \\
\hline & A01 & $22,350,123$ & 0.000001 & 6.1328 & $\mathrm{G} / \mathrm{A}$ \\
\hline & A01 & $22,376,230$ & 0.000001 & 6.1328 & $\mathrm{G} / \mathrm{A}$ \\
\hline & A01 & $22,387,777$ & 0.000001 & 6.1328 & $\mathrm{~T} / \mathrm{G}$ \\
\hline & D01 & $16,458,204$ & 0.000001 & 6.1328 & $\mathrm{C} / \mathrm{A}$ \\
\hline & D05 & $58,225,028$ & 0.000006 & 5.226497 & $\mathrm{~T} / \mathrm{C}$ \\
\hline & D05 & $58,227,014$ & 0.000015 & 4.83936 & $\mathrm{~T} / \mathrm{C}$ \\
\hline & D11 & $58,447,888$ & 0.000017 & 4.762019 & $\mathrm{C} / \mathrm{T}$ \\
\hline \multirow{3}{*}{ 7d Germination rate } & D05 & $12,154,352$ & 0.000028 & 4.560614 & $\mathrm{C} / \mathrm{A}$ \\
\hline & D05 & $12,155,655$ & 0.000030 & 4.516439 & $\mathrm{C} / \mathrm{T}$ \\
\hline & A05 & $12,181,224$ & 0.000078 & 4.109102 & $\mathrm{G} / \mathrm{A}$ \\
\hline \multirow{3}{*}{ 7d Germination weight } & D08 & $2,191,589$ & 0.000054 & 4.264409 & $\mathrm{G} / \mathrm{A}$ \\
\hline & D05 & $12,154,352$ & 0.000056 & 4.255444 & $\mathrm{C} / \mathrm{A}$ \\
\hline & D05 & $12,155,655$ & 0.000092 & 4.035935 & $\mathrm{C} / \mathrm{T}$ \\
\hline \multirow{8}{*}{ Relative germination rate } & D08 & $43,495,093$ & 0.000022 & 4.65032 & $\mathrm{~A} / \mathrm{G}$ \\
\hline & D08 & $43,541,365$ & 0.000027 & 4.57704 & $\mathrm{~A} / \mathrm{G}$ \\
\hline & D08 & $43,557,843$ & 0.000029 & 4.5365 & $\mathrm{~T} / \mathrm{C}$ \\
\hline & D08 & $43,483,056$ & 0.000033 & 4.48071 & $\mathrm{~A} / \mathrm{G}$ \\
\hline & D08 & $43,501,088$ & 0.000034 & 4.473257 & $\mathrm{C} / \mathrm{T}$ \\
\hline & D08 & $43,479,511$ & 0.000035 & 4.458785 & $\mathrm{C} / \mathrm{T}$ \\
\hline & D01 & $54,316,248$ & 0.000051 & 4.28993 & $\mathrm{~T} / \mathrm{C}$ \\
\hline & D01 & $54,289,162$ & 0.000078 & 4.106987 & $\mathrm{C} / \mathrm{A}$ \\
\hline
\end{tabular}




\subsection{Association Analysis of Salt Tolerance Index Traits among Cotton Accessions}

The results of the GWAS under the optimal model of the salt tolerance index traits using BLUP were counted and explained, and the results are shown in Table 2. A total of 15 significant SNP-trait associations were detected $(-\log 10(p)>3)$ (Table 3). It was also found that among these 15 traits, only 4 traits had significant SNPs, while the $7 \mathrm{~d}$ Radicle weight index did not have a significant locus. This may be because this trait is more complicated and controlled by multiple minor QTLs (Figure 6). According to the Bonferroni correction principle, $-\log 10(p)>3.97(p=1 / \mathrm{n}, \mathrm{n}$ is the SNP numbers in this study) should be the threshold, but the Bonferroni correction is too stringent and no significant SNPs for two traits could be identified with this threshold. To obtain more associated SNPs, the significantly associated SNP markers with salt-tolerant-related traits were identified according to $-\log 10(p)>3.0[21,22]$.

Table 3. SNP sites related to salt tolerance index traits in cotton accessions.

\begin{tabular}{|c|c|c|c|c|c|}
\hline Traits & Chromosomes & Position & $p$-Value & $-\log 10(p)$ & Alleles \\
\hline 7d Radicle length index & A11 & $85,527,572$ & 0.000058 & 4.236572 & $\mathrm{~T} / \mathrm{C}$ \\
\hline \multirow{7}{*}{$7 \mathrm{~d}$ Germination rate index } & A10 & $79,275,413$ & 0.000229 & 3.640165 & $\mathrm{C} / \mathrm{T}$ \\
\hline & D08 & $43,479,511$ & 0.000485 & 3.314258 & $\mathrm{C} / \mathrm{T}$ \\
\hline & D08 & $43,483,056$ & 0.000485 & 3.314258 & $\mathrm{~A} / \mathrm{G}$ \\
\hline & D08 & $43,495,093$ & 0.00034 & 3.468521 & $\mathrm{~A} / \mathrm{G}$ \\
\hline & D08 & $43,501,088$ & 0.000485 & 3.314258 & $\mathrm{C} / \mathrm{T}$ \\
\hline & D08 & $43,541,365$ & 0.000384 & 3.415669 & $\mathrm{~A} / \mathrm{G}$ \\
\hline & D08 & $43,557,843$ & 0.000495 & 3.305395 & $\mathrm{~T} / \mathrm{C}$ \\
\hline \multirow{6}{*}{ 3d Germination potential index } & A05 & $12,472,578$ & 0.000299 & 3.524329 & $\mathrm{~A} / \mathrm{G}$ \\
\hline & A05 & $12,473,346$ & 0.000675 & 3.170696 & $\mathrm{~A} / \mathrm{C}$ \\
\hline & D02 & $56,360,435$ & 0.000872 & 3.059484 & $\mathrm{~A} / \mathrm{G}$ \\
\hline & D05 & $3,861,440$ & 0.000815 & 3.088842 & $\mathrm{~T} / \mathrm{C}$ \\
\hline & D05 & $3,870,101$ & 0.000887 & 3.052076 & $\mathrm{~A} / \mathrm{G}$ \\
\hline & D05 & $3,873,693$ & 0.000301 & 3.521434 & $\mathrm{G} / \mathrm{A}$ \\
\hline 3d Radicle length index & D01 & 883,613 & 0.000872 & 3.059484 & $\mathrm{C} / \mathrm{T}$ \\
\hline
\end{tabular}
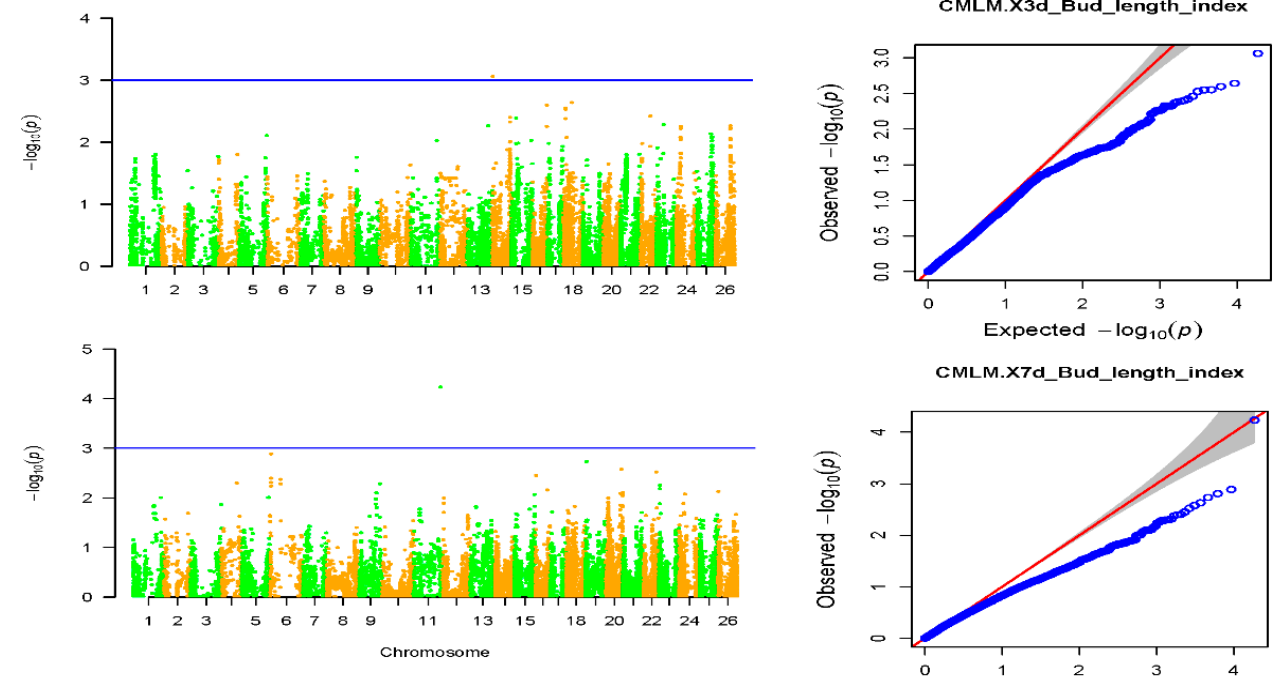

CMLM.X7d_Bud_length_index

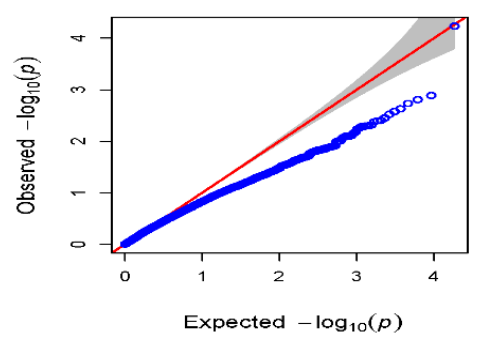

Figure 6. Cont. 

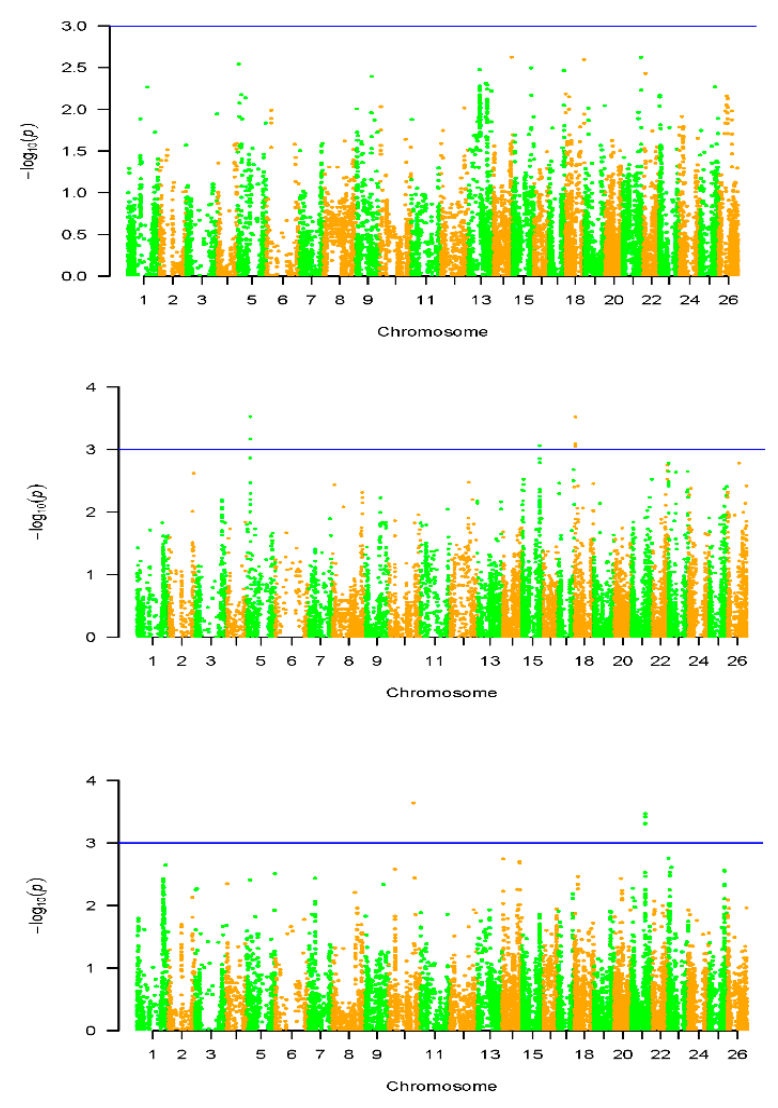

CMLM.X7d_Bud_weight_index

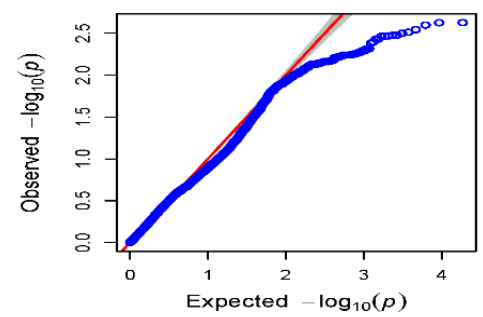

CMLM.X3d_Germination_potential_index

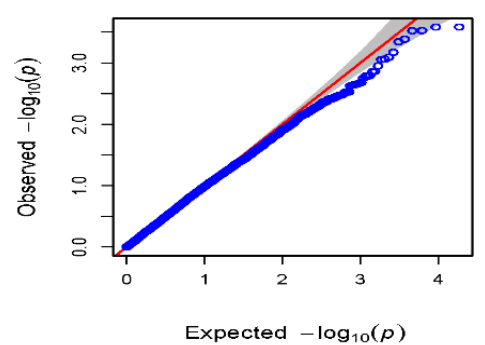

CMLM.X7d_Germination_rate_index

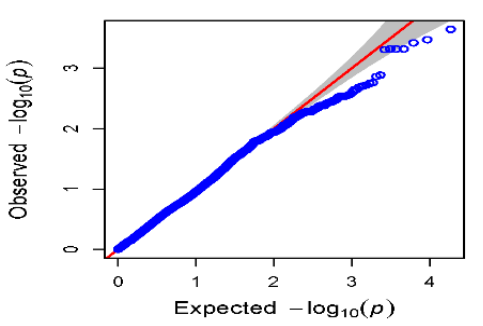

Figure 6. Manhattan and QQ charts of the 5 salt tolerance index traits. Manhattan graph: the abscissa represents the position of the chromosome, the ordinate represents the $-\log 10(p)$ taking the negative logarithm based on 10, and the scattered dots (or lines) on the graph represent the corresponding data for each SNP site. The blue horizontal line is the threshold line. Scattered points (or lines) that exceed the threshold line are candidate sites. QQ chart: The abscissa represents the expected value, and the ordinate represents the observed value. The red line in the figure represents the $45^{\circ}$ centre line, and the grey area is the $95 \%$ confidence interval of the scattered points in the figure.

\subsection{Candidate Gene Screening}

To investigate the expression pattern of these genes during the seedling stage under salt stress tolerance, and to further screen the possible candidate genes involved in the salt response, these genes were analyzed using the expression level of the seedlings at $1,3,6$ and $12 \mathrm{~h}$ under $400 \mathrm{mM}$ salt concentration. The public transcriptome data sets were retrieved from ccNET (https:/ / structralbiology.cau.edu.cn.gossypium (accessed on 22 February 2020)) [23]. As a result, five notable SNP sites on chromosome A01 and two notable SNP sites on chromosome D01 associated with the 7d Radicle length drop rate were detected, three genes, Gh_D01G0943, Gh_D01G0944 and Gh_D01G0945, were found at $500 \mathrm{~kb}$ upstream and $500 \mathrm{~kb}$ downstream of the two relevant SNP sites in D01; ten genes, Gh_A01G0905, Gh_A01G0906,Gh_A01G0907,Gh_A01G0908,Gh_A01G0909, Gh_A01G0910,Gh_A01G0911,Gh_A01G0912,Gh_A01G0913 and Gh_A01G0914, were found at $500 \mathrm{~kb}$ upstream and $500 \mathrm{~kb}$ downstream of the five relevant SNP sites in A01. At the same time, six identical associated SNP loci were detected in the Relative germination rate and $7 \mathrm{~d}$ Germination rate index, all of which were on the D08 chromosome. Ten genes were detected in the upstream and downstream $500 \mathrm{~kb}$ of the associated SNP loci: Gh_D08G1305, Gh_D08G1306, Gh_D08G1307, Gh_D08G1308,Gh_D08G1309, Gh_D08G1310, Gh_D08G1311, Gh_D08G1312, Gh_D08G1313 and Gh_D08G1314 (Figure 7). These genes were aligned to the transcriptome data, selected for differentially expressed genes, and, finally, we identified 6 candidate genes associated with plant salt stress by gene func- 
tional annotation with previous findings (Table 4). The transcriptome results showed that Gh_D01G0945, Gh_A01G0906 and Gh_D08G1308 expression was down-regulated of salt stress; Gh_A01G0908 and Gh_D08G1309 expression was up-regulated of salt stress. Gh_D01G0943 expression reached their peak at $3 \mathrm{~h}$ of salt stress (Figure 8).
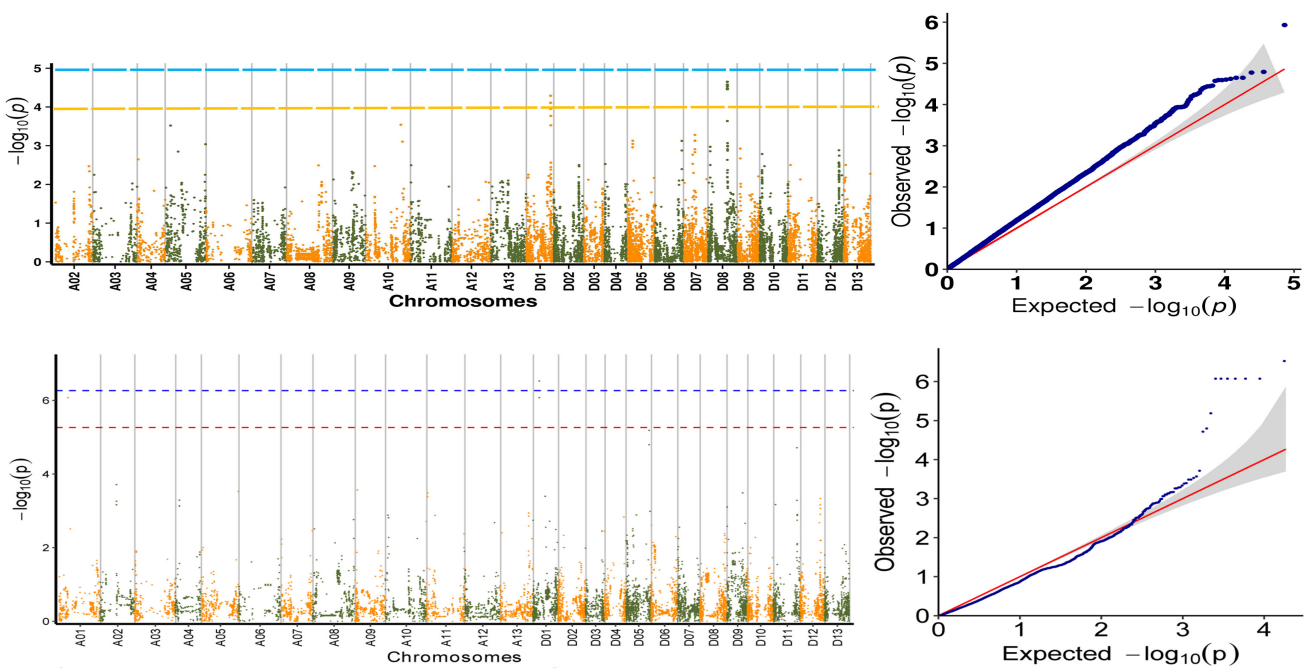

Figure 7. Screening of candidate genes for salt tolerance. Manhattan diagram: The abscissa represent chromosomal positions, the ordinate represents the $p$-value $(-\log 10(p))$ with a negative logarithm at 10 , and the scatter (or lines) on the figure represent the $-\log 10(p)$ corresponding to each SNP site. Blue horizontal line represents the value corresponding to 0.01 /marker quantity, and red horizontal line represents the value corresponding to 0.1 / marker quantity. A scatter (or line) above the threshold line is the candidate site. QQ chart: The abscissa represents the expected value, and the ordinate represents the observed value. The red line in the figure represents the $45^{\circ}$ centre line, and the grey area is the $95 \%$ confidence interval of the scattered points in the figure.

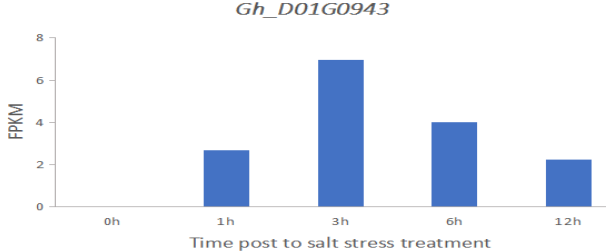

Gh_AO1G0906

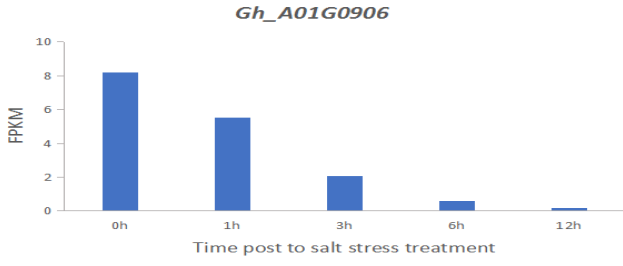

Gh_DO8G1308

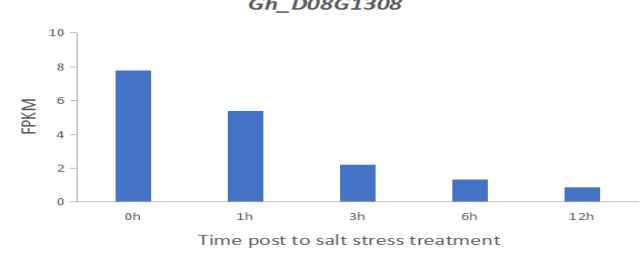

Gh_DO1G0945

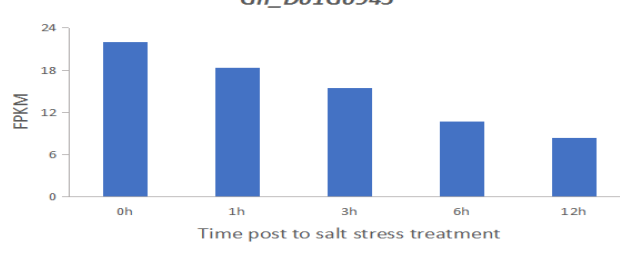

Gh_A01G0908

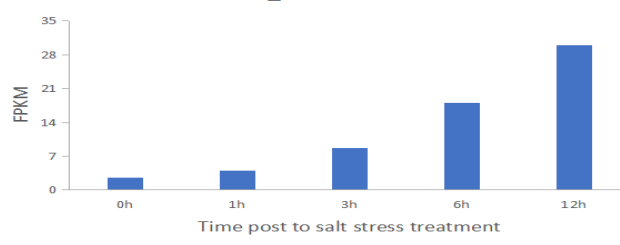

Gh_DO8G1309

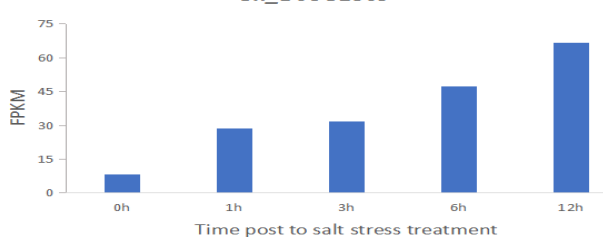

Figure 8. Transcriptome differentially expressed gene. 
Table 4. Genes associated with salt stress.

\begin{tabular}{ccc}
\hline Chromosomes & Gene & Position \\
\hline \multirow{2}{*}{ D01 } & Gh_D01G0943 & $15,976,403-15,982,586$ \\
& Gh_D01G0945 & $16,034,346-16,041,810$ \\
\hline \multirow{2}{*}{ A01 } & Gh_A01G0906 & $21,801,560-21,801,880$ \\
& Gh_A01G0908 & $22,204,069-22,208,876$ \\
\hline \multirow{2}{*}{ D08 } & Gh_D08G1308 & $43,063,260-43,063,640$ \\
& Gh_D08G1309 & $43,067,294-43,072,264$ \\
\hline
\end{tabular}

\subsection{Alignment of Salt Resistance-Related Genes and Arabidopsis Homologous Sequences}

The comparison of Gh_D01G0943 with Tair3 showed that the homologous gene in Arabidopsis thaliana is AT1G75680, with 76\% homology, and the gene is an GH9B7 glycosyl hydrolase 9B7. The comparison of Gh_D01G0945 with Tair3 showed that the homologous gene in Arabidopsis thaliana is AT1G77210, with 75\% homology, which encodes STP14 sugar transporter 14. The comparison of Gh_A01G0906 with Tair3 showed that the homologous gene in Arabidopsis thaliana is AT2G21220, with 78\% homology, and the gene is an SAUR-like auxin-responsive protein family. The comparison of Gh_A01G0908 with Tair3 showed that the homologous gene in Arabidopsis thaliana is AT1G19850, with 83\% homology, and the gene is an MP Transcriptional factor B3 family protein/auxin-responsive factor AUX/IAAlike protein. The comparison of Gh_D08G1308 with Tair3 showed that the homologous gene in Arabidopsis thaliana is AT5G18010, with 83\% homology, and the gene is an SAUR19 SAUR-like auxin-responsive protein family. The comparison of Gh_D08G1309 with Tair3 showed that the homologous gene in Arabidopsis thaliana is AT4G02280, with 75\% homology, and the gene is an SUS3 sucrose synthase 3 (Figure 9, Table 5). Both Gh_A01G0906 and Gh_D08G1308 Arabidopsis thaliana orthologs belong to SAUR-like auxin-responsive protein family, so both genes may have similar gene functions, the transcriptomic results showed similar expression patterns of both genes.
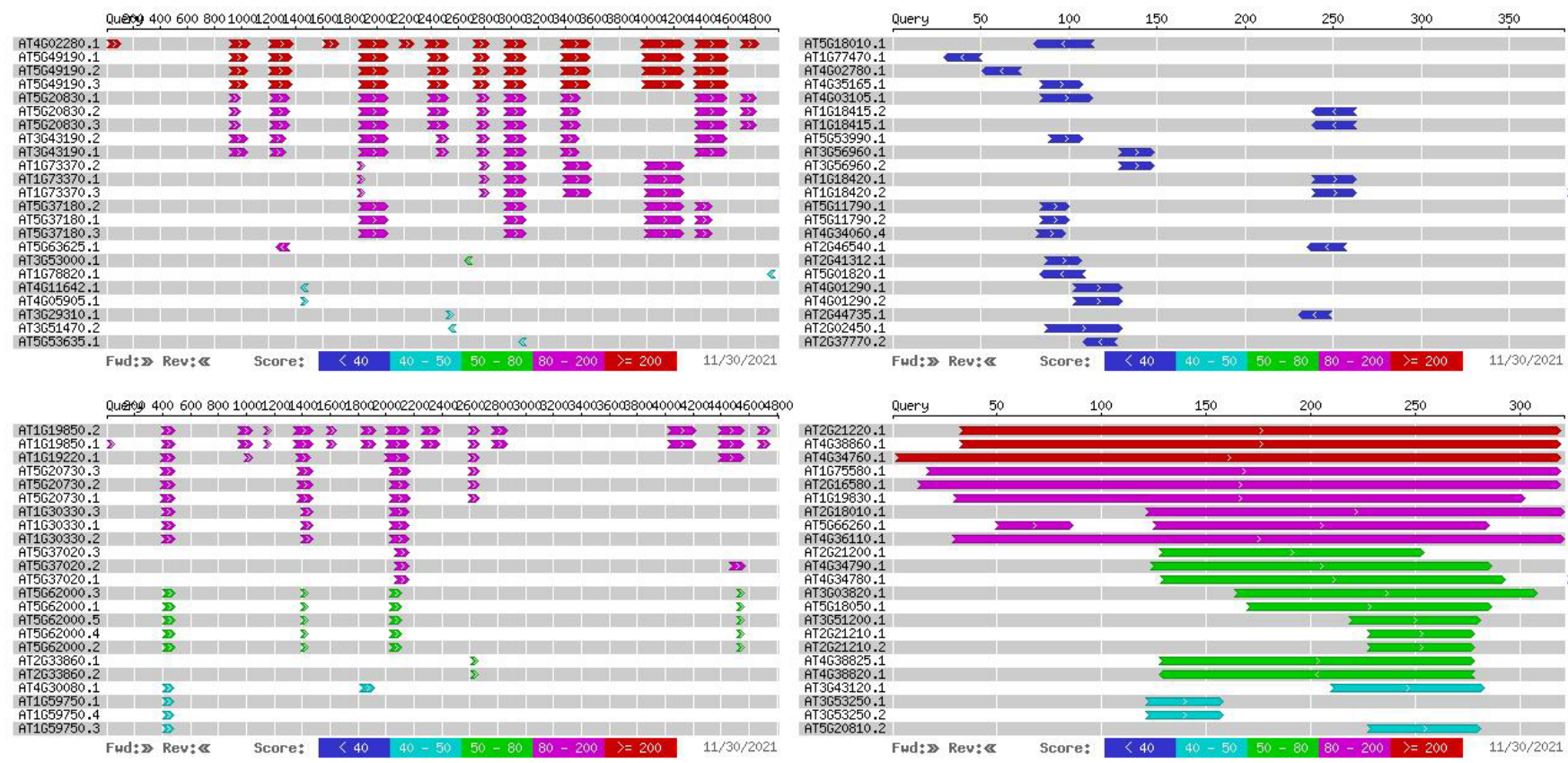

Figure 9. Cont. 

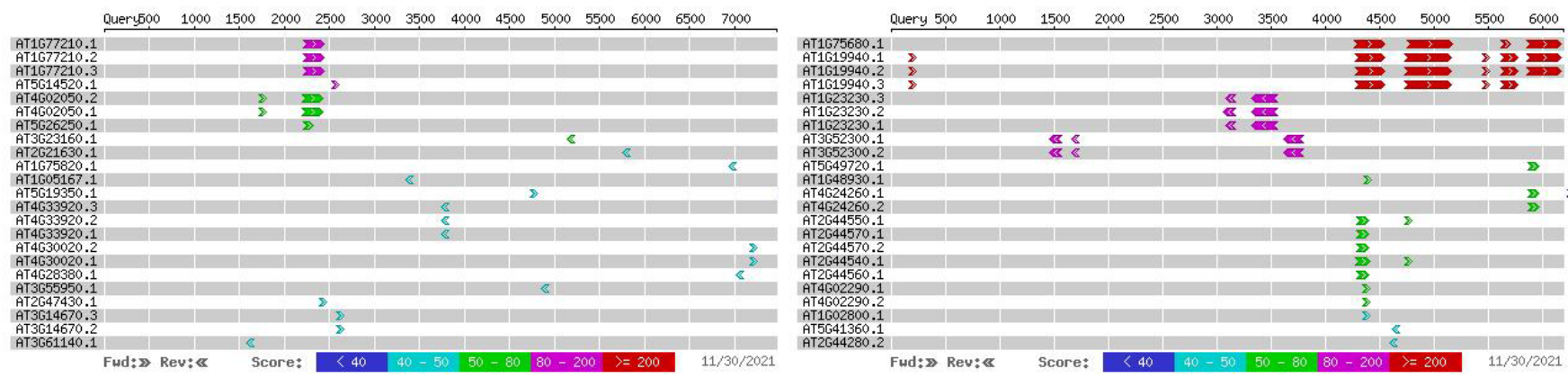

Figure 9. Gene sequence blast results.

Table 5. Genes associated with salt stress.

\begin{tabular}{cccc}
\hline Chromosomes & Gene & Arabidopsis Homology Gene & Homology Index \\
\hline \multirow{2}{*}{ D01 } & Gh_D01G0943 & AT1G75680 & $76 \%$ \\
& Gh_D01G0945 & AT1G77210 & $75 \%$ \\
\hline \multirow{2}{*}{ A01 } & Gh_A01G0906 & AT2G21220 & $78 \%$ \\
& Gh_A01G0908 & AT1G19850 & $83 \%$ \\
\hline \multirow{2}{*}{ D08 } & Gh_D08G1308 & AT5G18010 & $83 \%$ \\
& Gh_D08G1309 & AT4G02280 & $75 \%$ \\
\hline
\end{tabular}

\section{Discussion}

\subsection{Target Gene Identification Based on GWAS}

With the efficient development of genotyping technology, SNP markers have the advantages of wide distribution, high throughput, low cost and high accuracy. Genomewide association analysis based on SNP genetic markers has become the first choice for analyzing the complex traits of humans, animals and plants [24]. Some significant SNP markers in linkage disequilibrium can show a higher degree of linkage disequilibrium than those SNPs that actually cause phenotypic variation $[25,26]$.

Sun et al. (2018) identified 31 SSRs and 8 SNPs associated with salt tolerance based on relative seed germination rate under seven environments, using 503 upland cotton accessions and 179 SSRs and 11,975 array-derived SNPs [27]. Du et al. (2016) performed association analysis of 304 upland cotton cultivars and identified 95 significant associations for 10 salt tolerance-related traits at the germination and seedling stages [28]. Jia et al. (2014) identified three simple sequence repeat (SSR) markers significantly associated with the relative survival rate under salt stress through association mapping methods using $323 \mathrm{G}$. hirsutum germplasms. Two haplotypes related to fibre length and fibre strength were identified on chromosomes At07 and Dt11 [29]. Reddy et al. (2017) used GBS (genotypingby-sequencing) SNP typing technology to develop 10,129 polymorphic SNP markers from upland cotton and sea island cotton based on SNP markers and linkage disequilibrium LD from upland cotton and sea island cotton. A total of 142 and 282 blocks were excavated from sea island cotton [30].

In this study, Illumina Cotton SNP 70K was used to develop 18,430 SNP markers in the whole genome. On this basis, whole-genome association analysis was used to associate excellent sites related to salt tolerance traits and the salt tolerance index. The results of a total of 27 SNP sites related to salt tolerance traits were detected. The GWAS under the optimal model of the salt tolerance index traits using BLUP were counted and explained, a total of 15 significant SNP-trait associations were detected. 


\subsection{Functional Analysis of Candidate Genes}

Candidate genes are a class of genes whose expression on the chromosome is not clear. They are involved in the phenotypic expression of organisms, and association analysis suggests that they are related to a certain part of the genome. Such genes may be structural genes, regulatory genes or affect the expression of traits in biochemical metabolic pathways. The functional insufficiency of the candidate gene is known, and whether it is related to salt resistance has been verified. According to the screening, functional annotations can be assigned, or Arabidopsis homologous genes can be found from the gene information. This method has been previously reported to target genes that are clearly related to salt tolerance. GWAS analysis is a fast and powerful method to mine regulatory genes through crop indicators. A number of genes conferring salt tolerance such as MKK [31], ZFP [32], NAC [33], ERF [34], DREB [32], GhMT3a [35], MPK [36] and tonoplast $\mathrm{Na}+/ \mathrm{H}+$ antiporter [37] have been identified in cotton. Sun et al. (2018) reported that, among a total of 223 genes within a salt tolerance QTL interval on D01 $(37,771-1,942,912)$, four candidate genes (GhPIP3A, GhSAG29, GhTZF4 and GhTZF4a) showed a differential expression between sensitive and tolerant accessions under salt stress [10]. In this study, the comparison between our GWAS under the optimal model of the salt tolerance index traits for BLUP and previous reports showed that most of the 15 associations were novel reported loci. Abdelraheem et al. $(2017,2018)$ reported that each chromosome in each of the six pairs of homologous chromosomes (i.e., A01/D01, A03/D03, A08/D08, A09/D09, A12/D12 and A13/D13) had at least one ST (salt stress) QTL > 470,000 SNPs surveyed [38,39]. A total of 16 and 27 QTLs were identified for dry shoot weight and plant height, respectively, under both water-limited and saline environments, while 11 QTLs were found commonly linked with tolerance to drought and saline environments. Five striking SNP sites on chromosome A01, two striking SNP sites on chromosome D01 associated and six striking SNP sites on chromosome D08 were detected. The Gh_D01G0943, Gh_D01G0945, Gh_A01G0906, Gh_A01G0908, Gh_D08G1308 and Gh_D08G1309 gene associated with plant salt stress was detected at the associated SNP locus.

Sucrose synthase 3 (SUS3) catalyzes the reversible conversion of sucrose and a nucleoside diphosphate into the corresponding nucleoside diphosphate-glucose and fructose; a member of the glycosyltransferase family of enzymes, sucrose synthase 3 is ubiquitous in the plant kingdom and catalyzes in vivo and in vitro the synthesis and cleavage of sucrose. Sucrose synthase is one of the key enzymes in the plant carbohydrate metabolism and regulates the assignment of sucrose, a kind of product of photosynthesis, into a variety of plant metabolic processes. Sucrose synthase also plays pivotal roles during plant growth and development [40,41]; SUS is important for metabolite homeostasis and the timing of seed development and is a key enzyme of carbon metabolism in the heterotrophic tissues of plants [42,43]. SUS can transport sucrose into a variety of pathways, the most important of which provides a precursor substance (UDP-glucose) for the biosynthesis of cell wall polymers and starch [44]. In addition, SUS plays an important role in the process of growth, development and the metabolism of sink organs, and also plays an important role in the adaptation of plants to abiotic stress, such as hypoxia and cold; under hypoxia, the activity of SUS increased. SUS3 is induced in various organs under dehydration conditions including leaves deprived of water or submitted to osmotic stress as well as late-maturing seeds [45].

Sugar transporter 14 (STP14), as a transport protein, is a galactose transporter expressed in both source and sink tissues with the highest levels in the endosperm; it affects galactose transmembrane transporter activity, carbohydrate transmembrane transporter activity and sugar-hydrogen symporter activity [46]. STP are proton-coupled symporters responsible for the uptake of glucose from the apoplast into plant cells. They are integral to organ development in symplastically isolated tissues such as seed, pollen and fruit. Additionally, STPs play a vital role in plant responses to stressors such as dehydration and prevalent fungal infections such as rust and mildew [47]. STPs play a role in senescence 
and programmed cell death, and participate in the recycling of sugars derived from cell wall degradation $[46,48,49]$.

Glycosyl hydrolase 9B7 (GH9B7) is a kind of enzyme that hydrolyzes glycosidic bonds and plays an important role in the hydrolysis and synthesis of biological sugar and sugar conjugates. When the enzyme catalyzes the glycosidic reaction, if the oxygen atom of water molecule attacks the anomeric carbon on the receptor glucose, it will be hydrolyzed, but if the oxygen atom on the hydroxyl group of glucose attacks the anomeric carbon on the receptor glucose, it will be transglycosylated [50]. GH9B7 belong to glucosidase and their main function is to hydrolyze the glucoside bond, releasing glucose as a product. They are an indispensable class of enzymes in the glucose metabolism pathway of living organisms, involved in the carbohydrate metabolic process [51]. The process of N-glycosylation involves the participation of various enzymes, mainly glycoacyltransferases, including the transfer of active donors (usually NDP-sugar) to molecules of recipient substances such as sugars, proteins and lipids; the latter catalytic activity is to trim various glycochains, which together complete N-glycosylation. According to the current research results, it can be determined that the $\mathrm{N}$-glycosylation modification of the protein plays an important role in the processes of protein folding and transportation [52].

Transcriptional factor B3 family protein/auxin-responsive factor AUX/IAA-like protein $(M P)$, is an auxin-responsive transcription factor that is required for primary root formation and vascular development [53]. It plays a critical role in Arabidopsis embryonic root initiation, $M P$ transcriptionally initiates the ground tissue lineage and acts upstream of the regulatory network that controls ground tissue patterning and maintenance [54]. In the shoot, cell polarity patterns follow MP expression, which in turn follows auxin distribution patterns [55]. Signaling through MP/AUXIN RESPONSE FACTOR 5 is necessary for the formation of shoots from Arabidopsis calli [56]. Aux/IAA auxin perception mediates rapid cell wall acidification and growth of Arabidopsis hypocotyls [57]. AUX/IAA is a transcriptional repressor that has proved to play a very vital role in the auxin signaling pathway [58].

The plant hormone auxin controls numerous aspects of plant growth and development by regulating the expression of hundreds of genes. SMALL AUXIN UP RNA (SAUR) genes comprise the largest family of auxin-responsive genes; the SAUR19-24 subfamily of auxininduced SAUR genes promotes cell expansion [59]. SAUR proteins provide a mechanistic link between auxin and plasma membrane H+-ATPases (PM H+-ATPases) in Arabidopsis thaliana. Plants overexpressing stabilized SAUR19 fusion proteins exhibit increased $P M H+-A T P a s e$ activity, and the increased growth phenotypes conferred by SAUR19 overexpression are dependent upon normal PM H+-ATPase function. SAUR19 stimulates PM $H+$-ATPase activity by promoting phosphorylation of the C-terminal autoinhibitory domain. SAUR19, as well as additional SAUR proteins, interacts with the PP2C-D subfamily of type $2 \mathrm{C}$ protein phosphatases. These phosphatases are inhibited upon SAUR binding, act antagonistically to SAURs in vivo, can physically interact with PM H+-ATPases and negatively regulate $P M H+-A T P a s e$ activity [60]. SAURs play a central role in auxin-induced plant growth, but can also act independently of auxin, on tissue specifically regulated by various other hormone pathways and transcription factors [61].

Auxin functions, at least in part, by regulating a set of early auxin response genes: Aux/IAAs and SAURs [62]. Auxin is perceived by receptors including TRANSPORT INHIBITOR RESPONSE 1 (TIR1) and the closely related AUXIN SIGNALLING F-BOX (AFB) F-box proteins, which recruit Aux/IAA repressors to the SCFTIR1/AFB complex for ubiquitination and proteasome-mediated degradation, releasing the inhibition of AUXIN RESPONSE FACTORS (ARFs), and eventually activating auxin-induced gene expression [63]. The root growth inhibited by salt stress was related to the decrease in auxin accumulation. The position of auxin transporter $A U X 1$ is changed due to salt stress, so auxin transport may be related to decreased accumulation of auxin in the roots [64]. The accumulation of carbohydrates such as sucrose plays an important role in alleviating stress damage, including osmotic protection, carbon source storage and ROS removal. ASISH et al. (2004) showed that the intracellular reducing sugar (sucrose and fructan) levels of different species 
of plants are increased under salt stress [65]. In the process of salt stress response, the mechanisms or strategies that control the metabolism, transportation and balance of molecules, hormone metabolism, antioxidant metabolism and signal transduction mechanisms play a vital role in the process of plant adaptation to salt environment.

\section{Conclusions}

A total of 18,430 polymorphic SNP markers were developed and screened from natural populations using gene chip technology. These SNP markers were used to analyse the structure of the population to obtain the Q-matrix, and then the salt tolerance traits and salt tolerance index data were combined to conduct a genome-wide association analysis. The natural population can be divided into two subgroups. The genetic relationship between the cotton cultivars was weak; indicating that the breed inherited diversity is decreasing. The salt tolerance traits were associated with 27 significant SNP sites, and the salt tolerance index was associated with 15 significant SNP sites. The significant SNP sites were further analysed, salt tolerance-related Gh_D01G0943, Gh_D01G0945, Gh_A01G0906,Gh_A01G0908,Gh_D08G1308 and Gh_D08G1309 were detected in the spot data. The homologous sequences were compared with Arabidopsis thaliana to obtain the homologous genes AT1G75680, AT1G77210, AT2G21220, AT1G19850, AT5G18010 and AT4G02280. Analysis of the functions of these six genes revealed that the Arabidopsis thaliana homologous sequence encodes the glycosyl hydrolase 9B7, sugar transporter 14, sucrose synthase 3, SAUR-like auxin-responsive protein family and Transcriptional factor B3 family protein/auxin-responsive factor AUX/IAA-like protein. The sucrose-generating metabolic system, transmembrane transport system and regulation of the auxin response have high activity in the salt tolerance reaction of cotton, so the stability of the structure and function of the protective membrane and macromolecular matter are generated to maintain the cellular osmotic pressure balance and are the key to the salt tolerance of cotton. This study further analysed the functions and expression patterns of cotton salt-tolerant genes and even has certain reference value for analyzing the mechanism of cotton salt tolerance.

\section{Materials and Methods}

\subsection{Test Materials}

We sampled 149 modern G. hirsutum cultivars collected from the Chinese national medium-term cotton gene bank at the Institute of Cotton Research (ICR) of the Chinese Academy of Agricultural Sciences (CAAS) (Table 6).

Table 6. Sample number and name of cotton accessions/cultivars.

\begin{tabular}{|c|c|c|c|c|c|c|c|c|}
\hline Number & Breed Name & Origin & Number & Breed Name & Origin & Number & Breed Name & Origin \\
\hline 1 & Xinluzao No. 1 & $\begin{array}{c}\text { Inland } \\
\text { Northwest }\end{array}$ & 51 & $\begin{array}{l}\text { Xinluzhong } \\
\text { No. } 2\end{array}$ & $\begin{array}{c}\text { Inland } \\
\text { Northwest }\end{array}$ & 101 & Coker310 & Central Asia \\
\hline 2 & Xinluzao No. 2 & $\begin{array}{c}\text { Inland } \\
\text { Northwest }\end{array}$ & 52 & $\begin{array}{l}\text { Xinluzhong } \\
\text { No. } 6\end{array}$ & $\begin{array}{c}\text { Inland } \\
\text { Northwest }\end{array}$ & 102 & Dunhuang 77-116 & $\begin{array}{c}\text { Inland } \\
\text { Northwest }\end{array}$ \\
\hline 3 & Xinluzao No. 3 & $\begin{array}{c}\text { Inland } \\
\text { Northwest }\end{array}$ & 53 & $\begin{array}{l}\text { Xinluzhong } \\
\text { No. } 7\end{array}$ & $\begin{array}{c}\text { Inland } \\
\text { Northwest }\end{array}$ & 103 & Shan $63-1$ & $\begin{array}{c}\text { Yellow River } \\
\text { Basin }\end{array}$ \\
\hline 4 & Xinluzao No. 4 & $\begin{array}{c}\text { Inland } \\
\text { Northwest }\end{array}$ & 54 & $\begin{array}{l}\text { Xinluzhong } \\
\text { No. } 8\end{array}$ & $\begin{array}{c}\text { Inland } \\
\text { Northwest }\end{array}$ & 104 & Shanmian No. 9 & $\begin{array}{c}\text { Yellow River } \\
\text { Basin }\end{array}$ \\
\hline 5 & Xinluzao No. 5 & $\begin{array}{c}\text { Inland } \\
\text { Northwest }\end{array}$ & 55 & $\begin{array}{l}\text { Xinluzhong } \\
\text { No. } 9\end{array}$ & $\begin{array}{c}\text { Inland } \\
\text { Northwest }\end{array}$ & 105 & G164 220 & $\begin{array}{c}\text { Yellow River } \\
\text { Basin }\end{array}$ \\
\hline 6 & Xinluzao No. 7 & $\begin{array}{c}\text { Inland } \\
\text { Northwest }\end{array}$ & 56 & $\begin{array}{l}\text { Xinluzhong } \\
\text { No. } 10\end{array}$ & $\begin{array}{c}\text { Inland } \\
\text { Northwest }\end{array}$ & 106 & Jimian No. 11 & $\begin{array}{c}\text { Yellow River } \\
\text { Basin }\end{array}$ \\
\hline 7 & Xinluzao No. 8 & $\begin{array}{c}\text { Inland } \\
\text { Northwest }\end{array}$ & 57 & $\begin{array}{l}\text { Xinluzhong } \\
\text { No. } 11\end{array}$ & $\begin{array}{c}\text { Inland } \\
\text { Northwest }\end{array}$ & 107 & Lumian No. 17 & $\begin{array}{c}\text { Yellow River } \\
\text { Basin }\end{array}$ \\
\hline 8 & Xinluzao No. 9 & $\begin{array}{c}\text { Inland } \\
\text { Northwest }\end{array}$ & 58 & $\begin{array}{l}\text { Xinluzhong } \\
\text { No. } 12\end{array}$ & $\begin{array}{c}\text { Inland } \\
\text { Northwest }\end{array}$ & 108 & Lumian No. 28 & $\begin{array}{c}\text { Yellow River } \\
\text { Basin }\end{array}$ \\
\hline
\end{tabular}


Table 6. Cont.

\begin{tabular}{|c|c|c|c|c|c|c|c|c|}
\hline Number & Breed Name & Origin & Number & Breed Name & Origin & Number & Breed Name & Origin \\
\hline 9 & Xinluzao No. 10 & $\begin{array}{c}\text { Inland } \\
\text { Northwest }\end{array}$ & 59 & $\begin{array}{l}\text { Xinluzhong } \\
\text { No. } 14\end{array}$ & $\begin{array}{c}\text { Inland } \\
\text { Northwest }\end{array}$ & 109 & Lu 24 & $\begin{array}{c}\text { Yellow River } \\
\text { Basin }\end{array}$ \\
\hline 10 & Xinluzao No. 11 & $\begin{array}{c}\text { Inland } \\
\text { Northwest }\end{array}$ & 60 & $\begin{array}{l}\text { Xinluzhong } \\
\text { No. } 15\end{array}$ & $\begin{array}{c}\text { Inland } \\
\text { Northwest }\end{array}$ & 110 & Lu 25 & $\begin{array}{c}\text { Yellow River } \\
\text { Basin }\end{array}$ \\
\hline 11 & Xinluzao No. 12 & $\begin{array}{c}\text { Inland } \\
\text { Northwest }\end{array}$ & 61 & $\begin{array}{l}\text { Xinluzhong } \\
\text { No. } 16\end{array}$ & $\begin{array}{c}\text { Inland } \\
\text { Northwest }\end{array}$ & 111 & $\mathrm{Lu} 34$ & $\begin{array}{c}\text { Yellow River } \\
\text { Basin }\end{array}$ \\
\hline 12 & Xinluzao No. 13 & $\begin{array}{c}\text { Inland } \\
\text { Northwest }\end{array}$ & 62 & $\begin{array}{l}\text { Xinluzhong } \\
\text { No. } 17\end{array}$ & $\begin{array}{c}\text { Inland } \\
\text { Northwest }\end{array}$ & 112 & Yumian No. 17 & $\begin{array}{c}\text { Yangtze } \\
\text { River Basin }\end{array}$ \\
\hline 13 & Xinluzao No. 15 & $\begin{array}{c}\text { Inland } \\
\text { Northwest }\end{array}$ & 63 & $\begin{array}{l}\text { Xinluzhong } \\
\text { No. } 19\end{array}$ & $\begin{array}{c}\text { Inland } \\
\text { Northwest }\end{array}$ & 113 & Baimian No. 1 & $\begin{array}{c}\text { Yellow River } \\
\text { Basin }\end{array}$ \\
\hline 14 & Xinluzao No. 16 & $\begin{array}{c}\text { Inland } \\
\text { Northwest }\end{array}$ & 64 & $\begin{array}{l}\text { Xinluzhong } \\
\text { No. } 21\end{array}$ & $\begin{array}{c}\text { Inland } \\
\text { Northwest }\end{array}$ & 114 & Zhong 93001 & $\begin{array}{c}\text { Yellow River } \\
\text { Basin }\end{array}$ \\
\hline 15 & Xinluzao No. 17 & $\begin{array}{c}\text { Inland } \\
\text { Northwest }\end{array}$ & 65 & $\begin{array}{l}\text { Xinluzhong } \\
\text { No. } 22\end{array}$ & $\begin{array}{c}\text { Inland } \\
\text { Northwest }\end{array}$ & 115 & CCRI No. 12 & $\begin{array}{c}\text { Yellow River } \\
\text { Basin }\end{array}$ \\
\hline 16 & Xinluzao No. 18 & $\begin{array}{c}\text { Inland } \\
\text { Northwest }\end{array}$ & 66 & $\begin{array}{l}\text { Xinluzhong } \\
\text { No. } 26\end{array}$ & $\begin{array}{c}\text { Inland } \\
\text { Northwest }\end{array}$ & 116 & CCRI No. 16 & $\begin{array}{c}\text { Yellow River } \\
\text { Basin }\end{array}$ \\
\hline 17 & Xinluzao No. 19 & $\begin{array}{c}\text { Inland } \\
\text { Northwest }\end{array}$ & 67 & $\begin{array}{l}\text { Xinluzhong } \\
\text { No. } 27\end{array}$ & $\begin{array}{c}\text { Inland } \\
\text { Northwest }\end{array}$ & 117 & Zhongmian 41 & $\begin{array}{c}\text { Yellow River } \\
\text { Basin }\end{array}$ \\
\hline 18 & Xinluzao No. 20 & $\begin{array}{c}\text { Inland } \\
\text { Northwest }\end{array}$ & 68 & $\begin{array}{l}\text { Xinluzhong } \\
\text { No. } 28\end{array}$ & $\begin{array}{c}\text { Inland } \\
\text { Northwest }\end{array}$ & 118 & CCRI No. 43 & $\begin{array}{c}\text { Yellow River } \\
\text { Basin }\end{array}$ \\
\hline 19 & Xinluzao No. 21 & $\begin{array}{c}\text { Inland } \\
\text { Northwest }\end{array}$ & 69 & $\begin{array}{l}\text { Xinluzhong } \\
\text { No. } 30\end{array}$ & $\begin{array}{c}\text { Inland } \\
\text { Northwest }\end{array}$ & 119 & Emian No. 10 & $\begin{array}{c}\text { Yangtze } \\
\text { River Basin }\end{array}$ \\
\hline 20 & Xinluzao No. 23 & $\begin{array}{c}\text { Inland } \\
\text { Northwest }\end{array}$ & 70 & $\begin{array}{l}\text { Xinluzhong } \\
\text { No. } 32\end{array}$ & $\begin{array}{c}\text { Inland } \\
\text { Northwest }\end{array}$ & 120 & Emian No. 12 & $\begin{array}{c}\text { Yangtze } \\
\text { River Basin }\end{array}$ \\
\hline 21 & Xinluzao No. 24 & $\begin{array}{c}\text { Inland } \\
\text { Northwest }\end{array}$ & 71 & $\begin{array}{l}\text { Xinluzhong } \\
\text { No. } 34\end{array}$ & $\begin{array}{c}\text { Inland } \\
\text { Northwest }\end{array}$ & 121 & Emian No. 21 & $\begin{array}{c}\text { Yangtze } \\
\text { River Basin }\end{array}$ \\
\hline 22 & Xinluzao No. 25 & $\begin{array}{c}\text { Inland } \\
\text { Northwest }\end{array}$ & 72 & $\begin{array}{l}\text { Xinluzhong } \\
\text { No. } 35\end{array}$ & $\begin{array}{c}\text { Inland } \\
\text { Northwest }\end{array}$ & 122 & Wanmian 8407 & $\begin{array}{c}\text { Yangtze } \\
\text { River Basin }\end{array}$ \\
\hline 23 & Xinluzao No. 26 & $\begin{array}{c}\text { Inland } \\
\text { Northwest }\end{array}$ & 73 & $\begin{array}{l}\text { Xinluzhong } \\
\text { No. } 36\end{array}$ & $\begin{array}{c}\text { Inland } \\
\text { Northwest }\end{array}$ & 123 & Sumian No. 8 & $\begin{array}{c}\text { Yangtze } \\
\text { River Basin }\end{array}$ \\
\hline 24 & Xinluzao No. 27 & $\begin{array}{c}\text { Inland } \\
\text { Northwest }\end{array}$ & 74 & $\begin{array}{l}\text { Xinluzhong } \\
\text { No. } 38\end{array}$ & $\begin{array}{c}\text { Inland } \\
\text { Northwest }\end{array}$ & 124 & Sumian No. 12 & $\begin{array}{c}\text { Yangtze } \\
\text { River Basin }\end{array}$ \\
\hline 25 & Xinluzao No. 29 & $\begin{array}{c}\text { Inland } \\
\text { Northwest }\end{array}$ & 75 & $\begin{array}{l}\text { Xinluzhong } \\
\text { No. } 39\end{array}$ & $\begin{array}{c}\text { Inland } \\
\text { Northwest }\end{array}$ & 125 & Suyuan 04-129 & $\begin{array}{c}\text { Yangtze } \\
\text { River Basin }\end{array}$ \\
\hline 26 & Xinluzao No. 30 & $\begin{array}{c}\text { Inland } \\
\text { Northwest }\end{array}$ & 76 & $\begin{array}{l}\text { Xinluzhong } \\
\text { No. } 40\end{array}$ & $\begin{array}{c}\text { Inland } \\
\text { Northwest }\end{array}$ & 126 & Ganmian No. 10 & $\begin{array}{c}\text { Yangtze } \\
\text { River Basin }\end{array}$ \\
\hline 27 & Xinluzao No. 31 & $\begin{array}{c}\text { Inland } \\
\text { Northwest }\end{array}$ & 77 & $\begin{array}{l}\text { Xinluzhong } \\
\text { No. } 41\end{array}$ & $\begin{array}{c}\text { Inland } \\
\text { Northwest }\end{array}$ & 127 & Ganmian No. 17 & $\begin{array}{c}\text { Yangtze } \\
\text { River Basin }\end{array}$ \\
\hline 28 & Xinluzao No. 32 & $\begin{array}{c}\text { Inland } \\
\text { Northwest }\end{array}$ & 78 & $\begin{array}{l}\text { Xinluzhong } \\
\text { No. } 42\end{array}$ & $\begin{array}{c}\text { Inland } \\
\text { Northwest }\end{array}$ & 128 & Chuan 732720 & $\begin{array}{c}\text { Yangtze } \\
\text { River Basin }\end{array}$ \\
\hline 29 & Xinluzao No. 33 & $\begin{array}{c}\text { Inland } \\
\text { Northwest }\end{array}$ & 79 & $\begin{array}{l}\text { Xinluzhong } \\
\text { No. } 44\end{array}$ & $\begin{array}{c}\text { Inland } \\
\text { Northwest }\end{array}$ & 129 & Yumian No. 1 & $\begin{array}{c}\text { Yangtze } \\
\text { River Basin }\end{array}$ \\
\hline 30 & Xinluzao No. 34 & $\begin{array}{c}\text { Inland } \\
\text { Northwest }\end{array}$ & 80 & $\begin{array}{l}\text { Xinluzhong } \\
\text { No. } 45\end{array}$ & $\begin{array}{c}\text { Inland } \\
\text { Northwest }\end{array}$ & 130 & Liaomian No. 9 & $\begin{array}{c}\text { Special } \\
\text { precocious } \\
\text { cotton area }\end{array}$ \\
\hline 31 & Xinluzao No. 35 & $\begin{array}{c}\text { Inland } \\
\text { Northwest }\end{array}$ & 81 & $\begin{array}{l}\text { Xinluzhong } \\
\text { No. } 46\end{array}$ & $\begin{array}{c}\text { Inland } \\
\text { Northwest }\end{array}$ & 131 & Liaomian No. 16 & $\begin{array}{c}\text { Special } \\
\text { precocious } \\
\text { cotton area }\end{array}$ \\
\hline 32 & Xinluzao No. 36 & $\begin{array}{c}\text { Inland } \\
\text { Northwest }\end{array}$ & 82 & $\begin{array}{l}\text { Xinluzhong } \\
\text { No. } 50\end{array}$ & $\begin{array}{c}\text { Inland } \\
\text { Northwest }\end{array}$ & 132 & Dai-80 & America \\
\hline 33 & Xinluzao No. 37 & $\begin{array}{c}\text { Inland } \\
\text { Northwest }\end{array}$ & 83 & $\begin{array}{l}\text { Xinluzhong } \\
\text { No. } 54\end{array}$ & $\begin{array}{c}\text { Inland } \\
\text { Northwest }\end{array}$ & 133 & $\begin{array}{c}\text { Montenegro cotton } \\
\text { No. } 1\end{array}$ & $\begin{array}{c}\text { Special } \\
\text { precocious } \\
\text { cotton area }\end{array}$ \\
\hline
\end{tabular}


Table 6. Cont.

\begin{tabular}{|c|c|c|c|c|c|c|c|c|}
\hline Number & Breed Name & Origin & Number & Breed Name & Origin & Number & Breed Name & Origin \\
\hline 34 & Xinluzao No. 38 & $\begin{array}{c}\text { Inland } \\
\text { Northwest }\end{array}$ & 84 & $\begin{array}{l}\text { Xinluzhong } \\
\text { No. } 56\end{array}$ & $\begin{array}{c}\text { Inland } \\
\text { Northwest }\end{array}$ & 134 & Pidcotton & $\begin{array}{c}\text { Yellow River } \\
\text { Basin }\end{array}$ \\
\hline 35 & Xinluzao No. 39 & $\begin{array}{c}\text { Inland } \\
\text { Northwest }\end{array}$ & 85 & $\begin{array}{l}\text { Xinluzhong } \\
\text { No. } 58\end{array}$ & $\begin{array}{c}\text { Inland } \\
\text { Northwest }\end{array}$ & 135 & MacNair 210 & America \\
\hline 36 & Xinluzao No. 40 & $\begin{array}{c}\text { Inland } \\
\text { Northwest }\end{array}$ & 86 & $\begin{array}{l}\text { Xinluzhong } \\
\text { No. } 59\end{array}$ & $\begin{array}{c}\text { Inland } \\
\text { Northwest }\end{array}$ & 136 & Huazhong 106 & $\begin{array}{c}\text { Yangtze } \\
\text { River Basin }\end{array}$ \\
\hline 37 & Xinluzao No. 41 & $\begin{array}{c}\text { Inland } \\
\text { Northwest }\end{array}$ & 87 & $\begin{array}{l}\text { Xinluzhong } \\
\text { No. } 60\end{array}$ & $\begin{array}{c}\text { Inland } \\
\text { Northwest }\end{array}$ & 137 & Keyuan No. 1 & $\begin{array}{c}\text { Yellow River } \\
\text { Basin }\end{array}$ \\
\hline 38 & Xinluzao No. 42 & $\begin{array}{c}\text { Inland } \\
\text { Northwest }\end{array}$ & 88 & $\begin{array}{l}\text { Xinluzhong } \\
\text { No. } 61\end{array}$ & $\begin{array}{c}\text { Inland } \\
\text { Northwest }\end{array}$ & 138 & Bu 3363 & America \\
\hline 39 & Xinluzao No. 45 & $\begin{array}{c}\text { Inland } \\
\text { Northwest }\end{array}$ & 89 & $\begin{array}{l}\text { Xinluzhong } \\
\text { No. } 62\end{array}$ & $\begin{array}{c}\text { Inland } \\
\text { Northwest }\end{array}$ & 139 & Bamian No. 1 & $\begin{array}{c}\text { Yangtze } \\
\text { River Basin }\end{array}$ \\
\hline 40 & Xinluzao No. 46 & $\begin{array}{c}\text { Inland } \\
\text { Northwest }\end{array}$ & 90 & $\begin{array}{l}\text { Xinluzhong } \\
\text { No. } 63\end{array}$ & $\begin{array}{c}\text { Inland } \\
\text { Northwest }\end{array}$ & 140 & Chad No. 3 & Africa \\
\hline 41 & Xinluzao No. 47 & $\begin{array}{c}\text { Inland } \\
\text { Northwest }\end{array}$ & 91 & $\begin{array}{l}\text { Xinluzhong } \\
\text { No. } 64\end{array}$ & $\begin{array}{c}\text { Inland } \\
\text { Northwest }\end{array}$ & 141 & $\begin{array}{l}\text { Turkmen upland } \\
\text { cotton }\end{array}$ & Central Asia \\
\hline 42 & Xinluzao No. 48 & $\begin{array}{c}\text { Inland } \\
\text { Northwest }\end{array}$ & 92 & $\begin{array}{l}\text { Xinluzhong } \\
\text { No. } 65\end{array}$ & $\begin{array}{c}\text { Inland } \\
\text { Northwest }\end{array}$ & 142 & $\begin{array}{l}\text { NO Phenphenol } \\
\text { phenol No. } 1\end{array}$ & $\begin{array}{c}\text { Yangtze } \\
\text { River Basin }\end{array}$ \\
\hline 43 & Xinluzao No. 49 & $\begin{array}{c}\text { Inland } \\
\text { Northwest }\end{array}$ & 93 & $\begin{array}{l}\text { Xinluzhong } \\
\text { No. } 68\end{array}$ & $\begin{array}{c}\text { Inland } \\
\text { Northwest }\end{array}$ & 143 & Miscot7803-52 & America \\
\hline 44 & Xinluzao No. 50 & $\begin{array}{c}\text { Inland } \\
\text { Northwest }\end{array}$ & 94 & $\begin{array}{l}\text { Xinluzhong } \\
\text { No. } 69\end{array}$ & $\begin{array}{c}\text { Inland } \\
\text { Northwest }\end{array}$ & 144 & Si-6524 & Central Asia \\
\hline 45 & Xinluzao No. 51 & $\begin{array}{c}\text { Inland } \\
\text { Northwest }\end{array}$ & 95 & Xinlu 201 & $\begin{array}{c}\text { Inland } \\
\text { Northwest }\end{array}$ & 145 & Sparculent H10 & America \\
\hline 46 & Xinluzao No. 52 & $\begin{array}{c}\text { Inland } \\
\text { Northwest }\end{array}$ & 96 & Xinlu 202 & $\begin{array}{c}\text { Inland } \\
\text { Northwest }\end{array}$ & 146 & Yinmian No. 1 & $\begin{array}{c}\text { Yellow River } \\
\text { Basin }\end{array}$ \\
\hline 47 & Xinluzao No. 53 & $\begin{array}{c}\text { Inland } \\
\text { Northwest }\end{array}$ & 97 & Nongken No. 5 & $\begin{array}{c}\text { Inland } \\
\text { Northwest }\end{array}$ & 147 & America 28114-313 & America \\
\hline 48 & Xinluzao No. 60 & $\begin{array}{c}\text { Inland } \\
\text { Northwest }\end{array}$ & 98 & $\begin{array}{c}\text { Shache Soil } \\
\text { cotton }\end{array}$ & $\begin{array}{c}\text { Inland } \\
\text { Northwest }\end{array}$ & 148 & Columbia & $\begin{array}{c}\text { South } \\
\text { America }\end{array}$ \\
\hline 49 & Xinluzao No. 61 & $\begin{array}{c}\text { Inland } \\
\text { Northwest }\end{array}$ & 99 & Kuche T94-4 & $\begin{array}{c}\text { Inland } \\
\text { Northwest }\end{array}$ & 149 & Miscot 8711ne & America \\
\hline 50 & Xinluzhong No. 1 & $\begin{array}{c}\text { Inland } \\
\text { Northwest }\end{array}$ & 100 & Bazhou 6510 & $\begin{array}{c}\text { Inland } \\
\text { Northwest }\end{array}$ & & & \\
\hline
\end{tabular}

\subsection{DNA Extraction and Genotyping}

All cotton seeds were grown in a soil mixture in a fully automated greenhouse under a 12-h light/12-h dark cycle at $28^{\circ} \mathrm{C}$. Total genomic DNA was extracted from 5-day-old seedlings germinated from five well-developed seeds of each accession using a Qiagen $\mathrm{D}$ Neasy plant mini kit (Qiagen, CA, USA) following the protocol provided by the manufacturer. Genotyping was conducted at the CapitalBio Technology Platform in China using the Illumina Cotton SNP 70k Beadchip (Illumina, Inc., San Diego, CA, USA). All genotype SNP calls were extracted from the raw data using GenomeStudio (Illumina). A QTL was declared when four significant SNPs at $1 \times 10^{-3}$ were detected within a $6 \mathrm{Mb}$ region, and a QTL cluster was declared when multiple QTL were overlapped or were within a $15-40 \mathrm{Mb}$ region [66-68]. The reference genome was:

Gossypium hirsutum (AD1) 'TM-1' genome NAU-NBI v1.1 a1.1.

\subsection{Molecular Genetic Diversity and Phylogenetic Analyses}

PHYLIP (http://evolution.genetics.washington.edu/phylip.html (accessed on 15 February 2020)) was used to calculate the genetic distance matrix of the sample, Notepad++ software was used to adjust the genetic distance matrix file into a suitable format. After generating the tree file, iTOL (https:/ /itol.embl.de/ (accessed on 18 February 2020)) was 
used to draw the NJ tree diagram. Software was used to construct based on the neighborjoining method and the p-distance model and bootstrapping was repeated 1000 times. Principal component analysis (PCA) was performed on cotton population materials using GCTA 1.93 software [69] using the detected SNPs. Then, R software was used to calculate the vector of each principal component and draw the PCA scatter plot. The SNP data of 149 experimental materials were detected by Illumina Cotton SNP 70K and filtered according to the minor allele frequency (MAF: 0.05) and site integrity (INT: 0.1). The clean reads were anchored to the cotton reference genome using Burrows-Wheeler Aligner (BWA). The SAM tools software was used to convert alignment files to BAM files. After 63,058 probe sequences were blast aligned with the genome, the optimal result screened out was the position of the SNP on the reference genome. SnpEff 4.0 [70] software was used to obtain the locations of the variable sites (intergenic zones, gene zones or CDS zones) in the reference genome and the effects of the variations (synonymous mutations, nonsynonymous mutations, etc.).

\subsection{Population Structure and Kinship Analysis}

ADMIXTURE V250 [71] software was used to analyze the group structure of the research materials. For the research group, the number of subgroups (K value) was preset to 1-20 for clustering, the clustering results were cross-validated, and the optimal number of clusters was determined according to the lowest cross-validation error rate. SPAGeDi 1.3 [72] software was used to estimate the relative kinship between two individuals in a natural population. The kinship itself is the relative value that defines the genetic similarity between two specific materials and the genetic similarity between any materials. Therefore, when the kinship value between the two materials is less than 0 , it is directly defined as 0 . Five independent runs were performed; the number of populations (K) was set from 1 to 20; the burn-in time and Markov chain Monte Carlo replication numbers was set to 10,000 . The optimal $\mathrm{K}$ value was determined by comparing the $\operatorname{LnP}(\mathrm{D})$ and $\Delta \mathrm{k}$ based on the rate of change in LnP (D) [73]. A Q-matrix produced by STRUCTURE listed the estimated membership coefficients in a cluster for the subsequent association analysis.

\subsection{Linkage Disequilibrium Analysis}

On the same chromosome, the linkage disequilibrium between two SNPs within a certain distance can be calculated (such as $1000 \mathrm{~kb}$ ), and the linkage disequilibrium strength is represented by $r^{2}$. The closer $r^{2}$ is to 1 , the stronger the strength of linkage disequilibrium. The SNP spacing is fit to $\mathrm{r}^{2}$, and a graph can be drawn to represent the variation of $\mathrm{r}^{2}$ with distance. Generally, the closer the SNP spacing is, the larger $r^{2}$ is, and the farther the SNP spacing is, the smaller $r^{2}$ is. The distance travelled when the maximum $r^{2}$ value drops to half is used as the LD decay distance (LDD) of linkage disequilibrium. The longer the LDD is, the smaller the probability of recombination within the same physical distance; the shorter the LDD is, the greater the probability of recombination within the same physical distance. Plink2 [74] software was used for LD analysis.

\subsection{Association Analysis of Salt Tolerance Traits}

The TASSEL5.0 (http:/ / www.maizegenetics.net/tassel (accessed on 26 February 2020)) software package, EMMAX (http:/ / genetics.cs.ucla.edu/emmax/ (accessed on 26 February 2020)) software package and FaST-LMM0.2.19 (https:/ / www.microsoft.com/en-us/ download/confirmation.aspx?id=52588 (accessed on 22 February 2020)) software package were employed to construct association tests of salt tolerance-related traits. Through a certain amount of population SNP marker data, combined with population structure and target trait phenotype data, the target region or site associated with the target trait can be located. 


\subsection{Salt Stress Conditions and Salt-Tolerant Trait Collection}

The salt tolerance test during the germination period used double-layer filter paper rolls to stand the plant upright. Two pieces of filter paper each $20 \mathrm{~cm}$ in length and width were cut, and one piece of filter paper was spread on the test bench with a sprayer containing $\mathrm{NaCl}$ solution. The filter paper was soaked, and 15 seeds were placed $2 \mathrm{~cm}$ down from the top of the filter paper. The filter paper was then placed vertically into the culture box. Approximately 30 rolled filter papers were placed in each culture box. The culture box was then placed at $28^{\circ} \mathrm{C}$, and the photoperiod was $10 \mathrm{~h} / 14 \mathrm{~h}(\mathrm{~L} / \mathrm{D})$, with heat preservation and culture in a constant temperature light incubator. The germination potential of seeds and the length of each seed were measured on the 3rd day, and the germination rate, Radicle length and stem fresh weight of the seeds were measured on the 7 th day. This process was repeated 3 times. The treatment concentrations of $\mathrm{NaCl}$ solution were $0 \mathrm{NaCl}(\mathrm{CK})$ and $150.0 \mathrm{mmol} / \mathrm{L} \mathrm{NaCl}$ (Table 7) [75-78].

Table 7. Salt tolerance traits and salt tolerance index.

\begin{tabular}{cc}
\hline Salt Tolerance Traits & Salt Tolerance Index \\
\hline 7d Germination rate & 3d Germination potential index \\
7d Germination weight & 7d Germination rate index \\
3d Radicle length & 7d Radicle weight index \\
7d Radicle length & 3d Radicle length index \\
Relative germination potential & 7d Radicle length index \\
Relative germination rate & \\
7d Radicle weight drop rate & \\
3d Germination potential & \\
7d Radicle length drop rate & \\
3d Radicle length drop rate & \\
\hline
\end{tabular}

The calculation formula analyzes the relative values of the salt stress environment and the control conversion. The germination standard is that the radicle is half the length of the seed. Germination weight is the weight of all biological materials after germination.

Relative germination potential $\%=$ germination potential of treated seeds $/$ germination potential of control seeds $\times 100 \%$.

Relative germination rate $\%=$ germination rate of treated seeds/germination rate of control seeds $\times 100 \%$.

Decrease rate $\%=($ treatment traits - control traits $) /$ control traits $\times 100 \%$.

Salt tolerance index:

$$
\mathrm{SI}=\frac{\mathrm{X}_{\mathrm{d}}}{\overline{\mathrm{X}}} \times \frac{\mathrm{X}_{\mathrm{d}}}{\mathrm{X}_{\mathrm{w}}}
$$

Note: $X_{d}$ and $X_{w}$ are the measured values of a certain index of each material under salt stress conditions and contrast conditions, respectively, and $\bar{X}$ is the average value of this index under salt stress conditions.

Germination potential:

$$
\mathrm{GP}=\frac{\mathrm{M}_{1}}{\mathrm{M}}
$$

Note: $\mathrm{M}_{1}$ : Number of normal germinating grains within days of germination potential; M: Number of seeds to be tested.

Statistical analysis of the phenotype of salt tolerance-related traits was performed by SPSS. SAS software was used to perform the best linear unbiased prediction (BLUP) for salt tolerance traits; the parameter is the default value. Software was used to perform correlation analysis for each trait based on the model of $\mathrm{mlm}, \mathrm{glm}, \mathrm{cmlm}$, emmax and fastlmm, and the result of the structure was used as a fixed effect. Due to the small number of environments and the existence of certain false positives, the CMLM model can reduce the false positives as much as possible, so the method of CMLM is adopted. The CMLMs were performed by simultaneously accounting for multiple levels of Q-matrix and K-matrix 
according to the methods described [79]. Among them, the mixed linear model formula of TASSEL software is as follows:

$$
\mathrm{y}=\mathrm{X} \alpha+\mathrm{Q} \beta+\mathrm{K} \mu+\mathrm{e}
$$

Note: SPAGeDi 1.3 [72] software was used to calculate the genetic relationship K between samples. The general linear model uses $Q$ population structure information, while the mixed linear model uses $Q+K$, which is the population structure and genetic relationship information. $\mathrm{X}$ is the genotype and $\mathrm{Y}$ is the phenotype. In the end, an association result can be obtained for each SNP site.

Salt stress cotton transcriptional group data download: Sequencing of allotetraploid cotton (Gossypium hirsutum L. acc. TM-1) provides a resource for fibre improvement. Nat Biotechnol, 2015, doi:10.1038/nbt.3207 [23].

\subsection{Prediction and Functional Annotation of Salt-Tolerant Candidate Genes}

The independent significant SNP sites selected by the GWAS analysis results and $\mathrm{LD}$ calculations, plus or minus $500 \mathrm{~kb}$ upstream and downstream of the physical location of each SNP site as the candidate gene physical location query area, were identified by mapping the gene or Arabidopsis homologous gene and annotating information to narrow down the target candidate genes. NCBI, COTTONGEN, CNKI, Tair3 and other websites were used to annotate gene functions and compare homologous sequences.

Author Contributions: Z.Z. was the executor of the experimental design and experimental research of this study; Z.Z. and Z.S. completed the data analysis and the writing of the paper; J.W., Y.L., Y.X. and Z.G. participated in the experimental design, experimental data collection and test results analysis; X.L. and J.Z. were the architects and directors of the project, guiding experimental design, data analysis, paper writing and modification. All authors have read and agreed to the published version of the manuscript.

Funding: This work was supported by, for J.Z.: the "Tianshan Innovation" team program in the Xinjiang Uygur Autonomous Region (2021D14007); J.Z.: the Doctoral Program of Cash Crops Research, Institute of Xinjiang Academy of Agricultural Science (JZRC2019B0243); X.Y.: the National Natural Science Foundation of China (No. 31760405 and U1903204).

Institutional Review Board Statement: The study did not involve humans or animals.

Informed Consent Statement: This study did not involve human studies.

Data Availability Statement: Data sharing is not applicable to this article as no new data were created or analyzed in this study. The file with the vcf with SNPs and the file with phenotyping have been uploaded as attachments.

Acknowledgments: We would like to thank Xinjiang Academy of Agricultural Sciences, China, for the cotton varieties provided for this study, Biomarker Technologies for the sequencing. Thanks to all of the people, units and enterprises who have provided help to this study.

Conflicts of Interest: No competing interest among all authors.

\section{References}

1. Liang, W.; Cui, W.; Ma, X.; Wang, G.; Huang, Z. Function of wheat Ta-UnP gene in enhancing salt tolerance in transgenic Arabidopsis and rice. Biochem. Biophys. Res. Commun. 2014, 450, 794-801. [CrossRef] [PubMed]

2. Ullah, A.; Sun, H.; Yang, X.; Zhang, X. Drought coping strategies in cotton: Increased crop per drop. Plant Biotechnol. J. 2017, 15, 271-284. [CrossRef] [PubMed]

3. Long Enecker, D.E. The influence of soil so linity upon fruiting and shedding, boll characteristics, fibre properties and yields of two cotton species. Soil Sci. 1973, 115, 294-302. [CrossRef]

4. Long Enecker, D.E. The influence of high so dium in soil upon fruiting and shedding, boll characteristics, fibre properties and yields of two cotton species. Soil Sci. 1974, 118, 387-396. [CrossRef]

5. Razzouk, S.; Whittington, W. Effects of salinity on cotton yield and quality. Field Crop Res. 1991, 26, 305-314. [CrossRef]

6. Xu, P.; Guo, Q.; Meng, S.; Zhang, X.; Xu, Z.; Guo, W.; Shen, X. Genome-wide association analysis reveals genetic variations and candidate genes associated with salt tolerance related traits in Gossypium hirsutum. BMC Genom. 2021, 22, 26. [CrossRef] 
7. Si, L.; Chen, J.; Huang, X.; Gong, H.; Luo, J.; Hou, Q.; Zhou, T.; Lu, T.; Zhu, J.; Shangguan, Y.; et al. OsSPL13 controls grain size in cultivated rice. Nat. Genet. 2016, 48, 447-456. [CrossRef]

8. Yasir, M.; He, S.; Sun, G.; Geng, X.; Pan, Z.; Gong, W.; Jia, Y.; Du, X. A Genome-Wide Association Study Revealed Key SNPs/Genes Associated With Salinity Stress Tolerance In Upland Cotton. Genes 2019, 10, 829.

9. Cai, C.; Zhu, G.; Zhang, T.; Guo, W. High-density $80 \mathrm{~K} \mathrm{SNP}$ array is a powerful tool for genotypng G hirsutum accessions and genome analysis. BMC Genom. 2017, 18, 654 .

10. Sun, H.; Meng, M.; Yan, Z.; Lin, Z.; Nie, X.; Yang, X. Genome-wide association mapping of stress-tolerance traits in cotton. Crop J. 2018, 7, 77-88. [CrossRef]

11. Huang, C.; Nie, X.; Shen, C.; You, C.; Li, W.; Zhao, W.; Zhang, X.; Lin, Z. Population structure and genetic basis of the agronomic traits of upland cotton China revealed by a genome-wide association study using high-density SNPs. Plant Biotechnol. J. 2017, 15, 1374-1386. [CrossRef]

12. Paterson, A.H.; Wendel, J.F.; Gundlach, H.; Guo, H.; Jenkins, J.; Jin, D.; Llewellyn, D.; Showmaker, K.C.; Shu, S.; Udall, J.; et al. Repeated polyploidization of Gossypium genomes and the evolution of spinnable cotton fibres. Nature 2012, 492, 423-427. [CrossRef]

13. Abdelraheem, A.; Thyssen, G.N.; Fang, D.D.; Jenkins, J.N.; Mccarty, J.C.; Wedegaertner, T.; Zhang, J. GWAS reveals consistent QTL for drought and salt tolerance in a MAGIC population of 550 lines derived from intermating of 11 Upland cotton (Gossypium hirsutum) parents. Mol. Genet. Genom. 2020, 296, 119-129. [CrossRef]

14. Taghizadeh, N.; Ranjbar, G.A.; Nematzadeh, G.A.; Moghaddam, M.R.R. Salt-related Genes Expression in Salt-Tolerant and Salt-Sensitive Cultivars of Cotton (Gossypium sp. L.) under NaCl Stress. J. Plant Mol. Breed. 2018, 6, 1-15.

15. Frouin, J.; Languillaume, A.; Mas, J.; Mieulet, D.; Boisnard, A.; Labeyrie, A.; Bettembourg, M.; Bureau, C.; Lorenzini, E.; Portefaix, M.; et al. Tolerance to mild salinity stress in japonica rice: A genome-wide association mapping study highlights calcium signaling and metabolism genes. PLOS ONE 2018, 13, e0190964. [CrossRef]

16. Ahmad, N.; Khan, M.O.; Islam, E.; Wei, Z.-Y.; McAusland, L.; Lawson, T.; Johnson, G.N.; Nixon, P.J. Contrasting Responses to Stress Displayed by Tobacco Overexpressing an Algal Plastid Terminal Oxidase in the Chloroplast. Front. Plant Sci. 2020, 11, 501. [CrossRef] [PubMed]

17. Stich, B.; Maurer, H.P.; Melchinger, A.E.; Frisch, M.; Heckenberger, M.; Van Der Voort, J.R.; Peleman, J.; Sørensen, A.P.; Reif, J.C. Comparison of Linkage Disequilibrium in Elite European Maize Inbred Lines using AFLP and SSR Markers. Mol. Breed. 2006, 17, 217-226. [CrossRef]

18. Yang, X.; Yan, J.; Zheng, Y.; Yu, J.; Li, J. Reviews of association analysis for quantitative traits in plants. Acta Agron. Sin. 2007, 33, 523-530.

19. Page, J.T.; Liechty, Z.S.; Alexander, R.H.; Clemons, K.; Hulse-Kemp, A.M.; Ashrafi, H.; Van Deynze, A.; Stelly, D.M.; Udall, J.A. DNA Sequence Evolution and Rare Homoeologous Conversion in Tetraploid Cotton. PLoS Genet. 2016, 12, e1006012. [CrossRef]

20. Wang, M.; Tu, L.; Yuan, D.; Zhu, D.; Shen, C.; Li, J.; Liu, F.; Pei, L.; Wang, P.; Zhao, G.; et al. Reference genome sequences of two cultivated allotetraploid cottons, Gossypium hirsutum and Gossypium barbadense. Nat. Genet. 2018, 51, 224-229. [CrossRef]

21. Hatzig, S.V.; Frisch, M.; Breuer, F.; Nesi, N.; Ducournau, S.; Wagner, M.-H.; Leckband, G.; Abbadi, A.; Snowdon, R.J. Genome-wide association mapping unravels the genetic control of seed germination and vigor in Brassica napus. Front. Plant Sci. 2015, 6, 221. [CrossRef] [PubMed]

22. Zhang, J.; Song, Q.; Cregan, P.B.; Nelson, R.L.; Wang, X.; Wu, J.; Jiang, G.-L. Genome-wide association study for flowering time, maturity dates and plant height in early maturing soybean (Glycine max) germplasm. BMC Genom. 2015, 16, 217. [CrossRef]

23. Zhang, T.; Hu, Y.; Jiang, W.; Fang, L.; Guan, X.; Chen, J.; Zhang, J.; Saski, C.A.; Scheffler, B.E.; Stelly, D.M.; et al. Sequencing of allotetraploid cotton (Gossypium hirsutum L. acc. TM-1) provides a resource for fiber improvement. Nat. Biotechnol. 2015, 33, 531-537. [CrossRef]

24. Huang, X.; Han, B. Natural variations and genome-wide assoclatton studies crop plants. Annu. Rev. Plant Bio. 2014, 165, 531-551. [CrossRef] [PubMed]

25. Platt, A.; Vilhjálmsson, B.J.; Nordborg, M. Conditions under whmh genome-wlde association studies will be positively mlsleadmg. Genetics 2010, 186, 1045-1052. [CrossRef]

26. Korte, A.; Farlow, A. The advantages and limitations of trait analysis with GWAS: A review. Plant Methods 2013, 9, 29. [CrossRef]

27. Sun, Z.; Li, H.; Zhang, Y.; Li, Z.; Ke, H.; Wu, L.; Zhang, G.; Wang, X.; Ma, Z. Identification of SNPs and Candidate Genes Associated With Salt Tolerance at the Seedling Stage in Cotton (Gossypium hirsutum L.). Front. Plant Sci. 2018, 9, 1011. [CrossRef] [PubMed]

28. Du, L.; Cai, C.; Wu, S.; Zhang, F.; Hou, S.; Guo, W. Evaluation and Exploration of Favorable QTL Alleles for Salt Stress Related Traits in Cotton Cultivars (G. hirsutum L.). PLoS ONE 2016, 11, e0151076. [CrossRef]

29. Jia, Y.-H.; Sun, J.-L.; Wang, X.-W.; Zhou, Z.-L.; Pan, Z.-E.; He, S.-P.; Pang, B.-Y.; Wang, L.-R.; DU, X.-M. Molecular Diversity and Association Analysis of Drought and Salt Tolerance in Gossypium hirsutum L. Germplasm. J. Integr. Agric. 2014, 13, 1845-1853. [CrossRef]

30. Reddy, U.K.; Nimmakayala, P.; Abburi, V.L.; Reddy, C.V.C.M.; Saminathan, T.; Percy, R.G.; John, Z.Y.; Frelichowski, J.; Udall, J.A.; Page, J.T.; et al. Genome-wlde divergence, haplotype distribution and population demographic hmtones for Gossypmm hwsutum and Gossypmm barbadense as revealed by genome-anchored SNPs. Sci. Rep. 2017, 7, 41285. [CrossRef]

31. Luo, X.; Wu, J.; Li, Y.; Nan, Z.; Guo, X.; Wang, Y.; Zhang, A.; Wang, Z.; Xia, G.; Tian, Y. Synergistic Effects of GhSOD1 and GhCAT1 Overexpression in Cotton Chloroplasts on Enhancing Tolerance to Methyl Viologen and Salt Stresses. PLoS ONE 2013, 8, e54002. [CrossRef] [PubMed] 
32. Guo, Y.; Yu, Y.; Wang, D.; Wu, C.; Yang, G.; Huang, J.; Zheng, C. GhZFP1, a novel CCCH-type zinc finger protein from cotton, enhances salt stress tolerance and fungal disease resistance in transgenic tobacco by interacting with GZIRD21A and GZIPR5. New Phytol. 2009, 183, 62-75. [CrossRef]

33. Meng, C.; Cai, C.; Zhang, T.; Guo, W. Characterization of six novel NAC genes and their responses to abiotic stresses in Gossypium hirsutum L. Plant Sci. 2009, 176, 352-359. [CrossRef]

34. Johnson, K.L.; Jones, B.J.; Bacic, A.; Schultz, C.J. The fasciclin-like arabinogalactan pro- teins of Arabidopsis. A multigene family of putative cell adhesion molecules. Plant Physiol. 2003, 133, 1911-1925. [CrossRef]

35. Xue, T.; Li, X.; Zhu, W.; Wu, C.; Yang, G.; Zheng, C. Cotton metallothionein GhMT3a, a reactive oxygen species scavenger, increased tolerance against abiotic stress in transgenic tobacco and yeast. J. Exp. Bot. 2008, 60, 339-349. [CrossRef] [PubMed]

36. Zhang, Y.; Wang, X.; Li, Z.; Zhang, G.; Ma, Z. Assessing genetic diversity of cotton cultivars using genomic and newly developed expressed sequence tag-derived microsatellite markers. Genet. Mol. Res. 2011, 10, 1462-1470. [CrossRef] [PubMed]

37. Wu, C.A.; Yang, G.D.; Meng, Q.W.; Zheng, C.C. The cotton GhNHX1 gene encoding a novel putative tonoplast Na+/H+ antiporter plays an important role in salt stress. Plant Cell Physiol. 2004, 45, 600-607. [CrossRef] [PubMed]

38. Abdelraheem, A.; Thyssen, G.; Jenkins, J.; McCarty, J.; Fang, D.D.; Zhang, J.F. A genome-wide association study of tolerance to biotic and abiotic stresses in a MAGIC population of upland cotton. In Proceedings of the 2018 Beltwild Cotton Conferences, San Antonio, TX, USA, 3-5 January 2018; p. 565.

39. Abdelraheem, A.; Liu, F.; Song, M.; Zhang, J.F. A meta-analysis of quantitative trait loci for abiotic and biotic stress resistance in tetraploid cotton. Mol. Genet. Genom. 2017, 292, 1221-1235. [CrossRef]

40. Baroja-Fernández, E.; Muñoz, F.J.; Li, J.; Bahaji, A.; Almagro, G.; Montero, M.; Etxeberria, E.; Hidalgo, M.; Sesma, M.T.; Pozueta-Romero, J. Sucrose synthase activity in the sus1/sus2/sus3/sus4 Arabidopsis mutant is sufficient to support normal cellulose and starch production. Proc. Natl. Acad. Sci. USA 2012, 109, 321-326. [CrossRef]

41. Li-Na, L.I.; Jian-Qiang, K. Gene Organization, Function and Application of Plant Sucrose Synthase. Chin. J. Biochem. Mol. Biol. 2015, 9, 904-913.

42. Angeles-Núñez, J.G.; Tiessen, A. Arabidopsis sucrose synthase 2 and 3 modulate metabolic homeostasis and direct carbon towards starch synthesis in developing seeds. Planta 2010, 232, 701-718. [CrossRef] [PubMed]

43. Angeles-Núñez, J.G.; Tiessen, A. Regulation of AtSUS2 and AtSUS3 by glucose and the transcription factor LEC2 in different tissues and at different stages of Arabidopsis seed development. Plant Mol. Biol. 2012, 78, 377-392. [CrossRef]

44. Wen, X.; Zhang, W.; Feng, Y.; Yu, X. Cloning and characterization of a sucrose synthase-encoding gene from muskmelon. Mol. Biol. Rep. 2009, 37, 695-702. [CrossRef] [PubMed]

45. Baud, S.; Vaultier, M.; Rochat, C. Structure and expression profile of the sucrose synthase multigene family in Arabidopsis. J. Exp. Bot. 2004, 55, 397-409. [CrossRef] [PubMed]

46. Poschet, G.; Hannich, B.; Büttner, M. Identification and Characterization of AtSTP14, a Novel Galactose Transporter from Arabidopsis. Plant Cell Physiol. 2010, 51, 1571-1580. [CrossRef]

47. Bavnhøj, L.; Paulsen, P.A.; Flores-Canales, J.C.; Schiøtt, B.; Pedersen, B.P. Molecular mechanism of sugar transport in plants unveiled by structures of glucose/H+ symporter STP10. Nat. Plants 2021, 7, 1409-1419. [CrossRef]

48. Nørholm, M.H.; Nour-Eldin, H.H.; Brodersen, P.; Mundy, J.; Halkier, B.A. Expression of the Arabidopsis high-affinity hexose transporter STP13 correlates with programmed cell death. FEBS Lett. 2006, 580, 2381-2387. [CrossRef]

49. Rottmann, T.M.; Klebl, F.; Schneider, S.; Kischka, D.; Rüscher, D.; Sauer, N.; Stadler, R. Sugar Transporter STP7 Specificity for l-Arabinose and d-Xylose Contrasts with the Typical Hexose Transporters STP8 and STP12. Plant Physiol. 2018, 176, 2330-2350. [CrossRef]

50. McBride, Z.; Chen, D.; Reick, C.; Xie, J.; Szymanski, D.B. Global Analysis of Membrane-associated Protein Oligomerization Using Protein Correlation Profiling. Mol. Cell. Proteom. 2017, 16, 1972-1989. [CrossRef]

51. Bissaro, B.; Monsan, P.; Fauré, R.; O’Donohue, M.J. Glycosynthesis in a waterworld: New insight into the molecular basis of transglycosylation in retaining glycoside hydrolases. Biochem. J. 2015, 467, 17-35. [CrossRef]

52. Honer, J.; Niemeyer, K.M.; Fercher, C.; Tissera, A.L.D.; Jaberolansar, N.; Jafrani, Y.M.; Zhou, C.; Caramelo, J.J.; Shewan, A.M.; Schulz, B.L.; et al. TorsinA folding and N-linked glycosylation are sensitive to redox homeostasis. Biochim. Biophys. Acta Mol. Cell Res. 2021, 1868, 119073. [CrossRef]

53. Konishi, M.; Donner, T.J.; Scarpella, E.; Yanagisawa, S. MONOPTEROS directly activates the auxin-inducible promoter of the Dof5.8 transcription factor gene in Arabidopsis thaliana leaf provascular cells. J. Exp. Bot. 2014, 66, 283-291. [CrossRef] [PubMed]

54. Möller, B.K.; Colette, A.; Xiang, D.; Williams, N.; López, L.G.; Yoshida, S.; Smit, M.; Datla, R.; Weijers, D. Auxin response cell-autonomously controls ground tissue initiation in the early Arabidopsis embryo. Proc. Natl. Acad. Sci. USA 2017, 114, E2533-E2539. [CrossRef] [PubMed]

55. Odat, O.; Gardiner, J.; Sawchuk, M.G.; Verna, C.; Donner, T.J.; Scarpella, E. Characterization of an allelic series in the MONOPTEROS gene of Arabidopsis. Genesis 2014, 52, 127-133. [CrossRef] [PubMed]

56. Ckurshumova, W.; Smirnova, T.; Marcos, D.; Zayed, Y.; Berleth, T. Irrepressible MONOPTEROS/ARF 5 promotes de novo shoot formation. New Phytol. 2014, 204, 556-566. [CrossRef] [PubMed]

57. Fendrych, M.; Leung, J.; Friml, J. TIR1/AFB-Aux/IAA auxin perception mediates rapid cell wall acidification and growth of Arabidopsis hypocotyls. eLife 2016, 5, e19048. [CrossRef] [PubMed] 
58. Niemeyer, M.; Castillo, E.M.; Ihling, C.H.; Iacobucci, C.; Wilde, V.; Hellmuth, A.; Hoehenwarter, W.; Samodelov, S.L.; Zurbriggen, M.D.; Kastritis, P.L.; et al. Author Correction: Flexibility of intrinsically disordered degrons in AUX/IAA proteins reinforces auxin co-receptor assemblies. Nat. Commun. 2021, 12, 1768. [CrossRef] [PubMed]

59. Spartz, A.K.; Lee, S.H.; Wenger, J.P.; Gonzalez, N.; Itoh, H.; Inzé, D.; Peer, W.A.; Murphy, A.S.; Overvoorde, P.J.; Gray, W.M. The SAUR19 subfamily of SMALL AUXIN UP RNA genes promote cell expansion. Plant J. 2012, 70, 978-990. [CrossRef]

60. Spartz, A.K.; Ren, H.; Park, M.Y.; Grandt, K.N.; Lee, S.H.; Murphy, A.S.; Sussman, M.R.; Overvoorde, P.J.; Gray, W.M. SAUR Inhibition of PP2C-D Phosphatases Activates Plasma Membrane H+-ATPases to Promote Cell Expansion in Arabidopsis. Plant Cell 2014, 26, 2129-2142. [CrossRef]

61. Stortenbeker, N.; Bemer, M. The SAUR gene family: The plant's toolbox for adaptation of growth and development. J. Exp. Bot. 2019, 70, 17-27. [CrossRef] [PubMed]

62. Park, J.-E.; Kim, Y.-S.; Yoon, H.-K.; Park, C.-M. Functional characterization of a small auxin-up RNA gene in apical hook development in Arabidopsis. Plant Sci. 2007, 172, 150-157. [CrossRef]

63. Leyser, O. Auxin signaling. Plant Physiol. 2018, 176, 465-479. [CrossRef] [PubMed]

64. Yu, Z.; Duan, X.; Luo, L.; Dai, S.; Ding, Z.; Xia, G. How Plant Hormones Mediate Salt Stress Responses. Trends Plant Sci. 2020, 25. [CrossRef]

65. Parida, A.K.; Das, A.B.; Mohanty, P. Investigations on the antioxidative defence responses to $\mathrm{NaCl}$ stress in a mangrove, Bruguiera parviflora: Differential regulations of isoforms of some antioxidative enzymes. Plant Growth Regul. 2004, 42, 213-226. [CrossRef]

66. Said, J.I.; Lin, Z.; Zhang, X.; Song, M.; Zhang, J. A comprehen- sive meta QTL analysis for fiber quality, yield, yield related and morphological traits, drought tolerance, and disease resistance in tetraploid cotton. BMC Genom. 2013, 14, 776. [CrossRef] [PubMed]

67. Said, J.I.; Song, M.; Wang, H.; Lin, Z.; Zhang, X.; Fang, D.D.; Zhang, J. A comparative Meta- analysis of QTL between intraspe- cific Gossypium hirsutum and interspecific G. hirsutum x G. bar- badense populations. Mol. Genet. Genom. 2015, 290, 1003-1025. [CrossRef]

68. Said, J.I.; Knapka, J.A.; Song, M.; Zhang, J. Cotton QTLdb: A cotton QTL database for QTL analysis, visualization, and comparison between Gossypium hirsutum and G. hirsutum x G. barbadense populations. Mol. Genet. Genom. 2015, 290, 1615-1625. [CrossRef]

69. Yang, J.; Lee, S.H.; Goddard, M.E.; Visscher, P.M. GCTA: A tool for genome-wide complex trait analysis. Am. J. Hum. Genet. 2011, 88, 76-82. [CrossRef] [PubMed]

70. Cingolani, P.; Platts, A.; Wang, L.L.; Coon, M.; Nguyen, T.; Wang, L.; Land, S.J.; Lu, X.; Ruden, D.M. A program for annotating and predicting the effects of single nucleotide polymorphisms, SnpEff: SNPs in the genome of Drosophila melanogaster strain w1118; iso-2; iso-3. Fly 2012, 6, 80-92. [CrossRef]

71. Alexander, D.H.; Novembre, J.; Lange, K. Fast model-based estimation of ancestry in unrelated individuals. Genome Res. 2009, 19, 1655-1664. [CrossRef]

72. Hardy, O.J.; Vekemans, X. SPAGeDi: A versatile computer program to analyse spatial genetic structure at the individual or population levels. Mol. Ecol. Notes 2002, 2, 618-620. [CrossRef]

73. Evanno, G.; Regnaut, S.; Goudet, J. Detecting the number of clusters of individuals using the software structure: A simulation study. Mol. Ecol. 2005, 14, 2611-2620. [CrossRef] [PubMed]

74. Purcell, S.; Neale, B.; Todd-Brown, K.; Thomas, L.; Ferreira, M.A.R.; Bender, D.; Maller, J.; Sklar, P.; de Bakker, P.I.W.; Daly, M.J.; et al. PLINK: A Tool Set for Whole-Genome Association and Population-Based Linkage Analyses. Am. J. Hum. Genet. 2007, 81, 559-575. [CrossRef] [PubMed]

75. Higbie, S.M.; Wang, F.; Stewart, J.M.; Sterling, T.M.; Lindemann, W.C.; Hughs, E.; Zhang, J. Physiological Response to Salt (NaCl) Stress in Selected Cultivated Tetraploid Cottons. Int. J. Agron. 2010, 2010, 643475. [CrossRef]

76. Tiwari, R.S.; Picchioni, G.A.; Steiner, R.L.; Hughs, S.E.; Jones, D.C.; Zhang, J. Genetic variation in salt tolerance during seed germina- tion in a backcross inbred line population and advanced breeding lines derived from Gossypium hirsutum x G. barbadense. Crop Sci. 2013, 53, 1974-1982. [CrossRef]

77. Tiwari, R.S.; Picchioni, G.A.; Steiner, R.L.; Jones, D.C.; Hughs, S.E.; Zhang, J. Genetic variation in salt tolerance at the seedling stage in an interspecific backcross inbred line population of cotton. Euphytica 2013, 194, 1-11. [CrossRef]

78. Barrick, B.; Steiner, R.; Picchioni, G.; Ulery, A.; Zhang, J. Salinity responses of selected introgression cotton grown in two soils. J. Cotton Sci. 2015, 19, 268-278.

79. Yu, J.; Pressoir, G.; Briggs, W.H.; Bi, I.V.; Yamasaki, M.; Doebley, J.F.; McMullen, M.D.; Gaut, B.S.; Nielsen, D.M.; Holland, J.B.; et al. A unified mixed-model method for association mapping that accounts for multiple levels of relatedness. Nat. Genet. 2006, 38, 203-208. [CrossRef] 